\title{
The Role of Gut Microbiota and Its Produced Metabolites in Obesity, Dyslipidemia, Adipocyte Dysfunction, and Its Interventions
}

\author{
Max S. Z. Zwartjes ${ }^{1,2, *(1)}$, Victor E. A. Gerdes ${ }^{1,2,3}$ and Max Nieuwdorp ${ }^{1,3,4}$ \\ 1 Department of Experimental Vascular Medicine, Amsterdam University Medical Center, \\ 1105 AZ Amsterdam, The Netherlands; v.e.gerdes@amsterdamumc.nl (V.E.A.G.); \\ m.nieuwdorp@amsterdamumc.nl (M.N.) \\ 2 Department of Internal Medicine, Spaarne Gasthuis, Spaarnepoort 1, 2134 TM Hoofddorp, The Netherlands \\ 3 Department of Internal and Vascular Medicine, Amsterdam University Medical Center, \\ 1105 AZ Amsterdam, The Netherlands \\ 4 Department of Internal Medicine, Diabetes Center, Amsterdam University Medical Center, \\ 1105 AZ Amsterdam, The Netherlands \\ * Correspondence: m.s.z.zwartjes@amsterdamumc.nl
}

\section{check for} updates

Citation: Zwartjes, M.S.Z.; Gerdes, V.E.A.; Nieuwdorp, M. The Role of Gut Microbiota and Its Produced Metabolites in Obesity, Dyslipidemia, Adipocyte Dysfunction, and Its Interventions. Metabolites 2021, 11, 531. https://doi.org/10.3390/ metabo11080531

Academic Editors: Isabel

Moreno-Indias and Carolina Gutiérrez-Repiso

Received: 26 July 2021

Accepted: 6 August 2021

Published: 10 August 2021

Publisher's Note: MDPI stays neutral with regard to jurisdictional claims in published maps and institutional affiliations.

Copyright: (c) 2021 by the authors. Licensee MDPI, Basel, Switzerland. This article is an open access article distributed under the terms and conditions of the Creative Commons Attribution (CC BY) license (https:// creativecommons.org/licenses/by/ $4.0 /)$.

\begin{abstract}
Obesity is becoming an increasing problem worldwide and is often, but not invariably, associated with dyslipidemia. The gut microbiota is increasingly linked to cardiovascular disease, nonalcoholic fatty liver disease, and type 2 diabetes mellitus. However, relatively little focus has been attributed to the role of gut-microbiota-derived metabolites in the development of dyslipidemia and alterations in lipid metabolism. In this review, we discuss current data involved in these processes and point out the therapeutic potentials. We cover the ability of gut microbiota metabolites to alter lipoprotein lipase action, VLDL secretion, and plasma triglyceride levels, and its effects on reverse cholesterol transport, adipocyte dysfunction, and adipose tissue inflammation. Finally, the current intervention strategies for treatment of obesity and dyslipidemia is addressed with emphasis on the role of gut microbiota metabolites and its ability to predict treatment efficacies.
\end{abstract}

Keywords: dyslipidemia; lipid metabolism; obesity; gut microbiota; metabolites; lipoprotein lipase; reverse cholesterol transport; bile acid receptors; adipocyte dysfunction; adipose tissue inflammation; lipid-lowering agents

\section{Introduction}

Obesity has approximately tripled from 1975 to 2016, affecting 650 million adults worldwide, and in 2016, 39\% of the world population was overweight [1]. Although obesity prevalence remains highest in high-income countries, obesity has increased in each and every World Bank income group and is becoming a rising problem in developing countries [2,3]. Obesity increases the risk of insulin resistance, glucose intolerance and type 2 diabetes mellitus (T2DM), nonalcoholic fatty liver disease (NAFLD), several types of cancer including breast, endometrial, and colorectal cancer, obstructive sleep apnea (OSA), and as discussed in this review, obesity is frequently accompanied by dyslipidemia with subsequent atherosclerotic cardiovascular disease (ASCVD) [4].

One of the most important triggers for atheroma formation within arterial walls and the resulting ASCVD is dyslipidemia, characterized by abnormal elevations and deposition of mainly Apo-B-containing lipoproteins including low-density lipoprotein cholesterol (LDL-C) $[5,6]$. The main reason we treat dyslipidemias is to prevent ASCVD, including coronary artery disease and stroke [7]. Since cardiovascular diseases continue to be the most common cause of mortality in low- to high-income countries [8] and alterations in the lipid profile are seen as one of its primary causes, the search for further pathogenetic mechanisms of dyslipidemia is highly relevant. Obesity is often associated with dyslipidemia; 
however, many patients with severe obesity do not have characteristics of dyslipidemia and although the designation of patients as 'metabolically healthy' is a topic of ongoing discussion, many patients with obesity might have underlying protective mechanisms against cardiometabolic disease, which remain to be discovered [9].

Recent research has increasingly focused on the role of gut microbiota (GM) and its metabolites in the pathogenesis of cardiometabolic disease [10,11], including T2DM, ASCVD, and NAFLD, with important microbially produced metabolites including the microbial formed trimethylamine (TMA) and its oxidized form TMAO, lipopolysaccharide (LPS), secondary bile acids, and the more recently discovered association of phenylacetylglutamine (PAG) and its role in thrombosis. However, relatively little interest has been paid to the possible role of gut microbiota and its produced metabolites in lipid metabolism in obesity and the development of dyslipidemia.

\section{Obesity and Dyslipidemia}

A surplus of caloric intake combined with a sedentary lifestyle and genetic predisposition causes the expansion of adipose tissue, termed obesity. Excess energy is efficiently stored as triglycerides within our adipocyte depots, and if required, energy can be released by lipolysis of triglycerides into free fatty acids (FFAs). Before discussing definitions of dyslipidemia and its pathogenetic mechanisms in obesity, we describe lipid metabolism in healthy persons.

\subsection{Normal Lipid Metabolism}

The circulating lipoproteins in our plasma are aggregate molecules composed of a lipid core with different concentrations of triglycerides and cholesteryl esters packed inside a phospholipid monolayer with scattered free cholesterol and surface apolipoproteins [12]. The contents inside the lipoproteins can be exogenous such as for chylomicrons synthesized by enterocytes or endogenous such as for very low-density lipoprotein (VLDL) synthesized by hepatocytes. Intermediate (IDL) and low-density lipoproteins (LDL) cholesterol are derived from further enzymatic steps [12]. Figure 1 summarizes the exogenous, endogenous, and reverse cholesterol transport mechanisms.

Exogenous lipids are the fats absorbed from our diet. The ingested lipids, primarily triglycerides (TGs), are turned into fatty acids (FAs) and 2-monoacylglycerol (2-MAG) by pancreatic lipase at the intestinal lumen [13]. Next, long-chain fatty acids, MAGs, cholesterol, and other lipid digestion-derived molecules are re-esterified inside enterocytes, forming TGs, phospholipids, and cholesteryl esters. In order to solubilize TGs and the cholesteryl esters, enterocytes pack lipids into apolipoprotein B48-positive (Apo-B48) chylomicrons released into lymph and circulation [14]. Dietary cholesterol uptake occurs with the help of Niemann-Pick C1-like 1 protein (NPC1L1) before cholesteryl ester formation and transport into chylomicrons [15]. Next, after chylomicron maturation by action of HDL (see below), mature chylomicrons are formed from which lipoprotein lipase can draw out free fatty acids, leaving chylomicron remnants through which ApoE binding to hepatocyte expressed receptors enters and is broken down within hepatocytes [16]. Notably, some products of luminal lipid digestion are water soluble and hence transported readily across the enterocyte via several membrane transporters to enter the portal blood; these products include glycerol, short-, and medium-chain fatty acids (SCFA, MCFA) [17].

The other class of lipids are endogenous lipids, formed under the high influence of insulin [18]. Endogenous TGs and other lipids are released as very low density lipoprotein (VLDL) by hepatocytes; after intake of a carbohydrate-rich meal, after further caloric intake when hepatic glycogen stores have already been repleted, excess glucose is converted into pyruvate [19]. Pyruvate inside the mitochondria converts into Acetyl-CoA, to enter the citric acid cycle (CAC) and fuse with oxaloacetate forming citrate, and citrate is pushed back into the cytoplasm, as during the further caloric intake, ATP and NADH molecules have already been produced in high numbers, causing citrate to exit the mitochondria and enter the cytoplasm. Cytosolic citrate once more forms Acetyl-CoA, and by insulin- 
activated enzymes, acetyl-CoA converts into malonyl-CoA, which eventually turns into fatty acids $[18,20]$. Cytoplasmic glycerol produced from parallel glycolysis binds with fatty acid, and by several steps, forms TGs. Cholesteryl ester is formed in other steps: in case of decreasing hepatic cholesterol, hepatic sterol regulatory element-binding protein (SREBP2) induces LDL-receptors to the surface in order to bind apoB-100 of lipoproteins such as LDL-C; in addition, SREBP2 induces HMG-CoA reductase for de novo cholesterol synthesis [21]. Altogether, this is de novo lipogenesis, generating endogenous lipids (TG) by the de novo synthesis of fatty acid during the excessive-energy nutrition status. The liver releases triglycerides inside VLDLs, which have apolipoprotein B100 (apoB-100) on its surface [22].

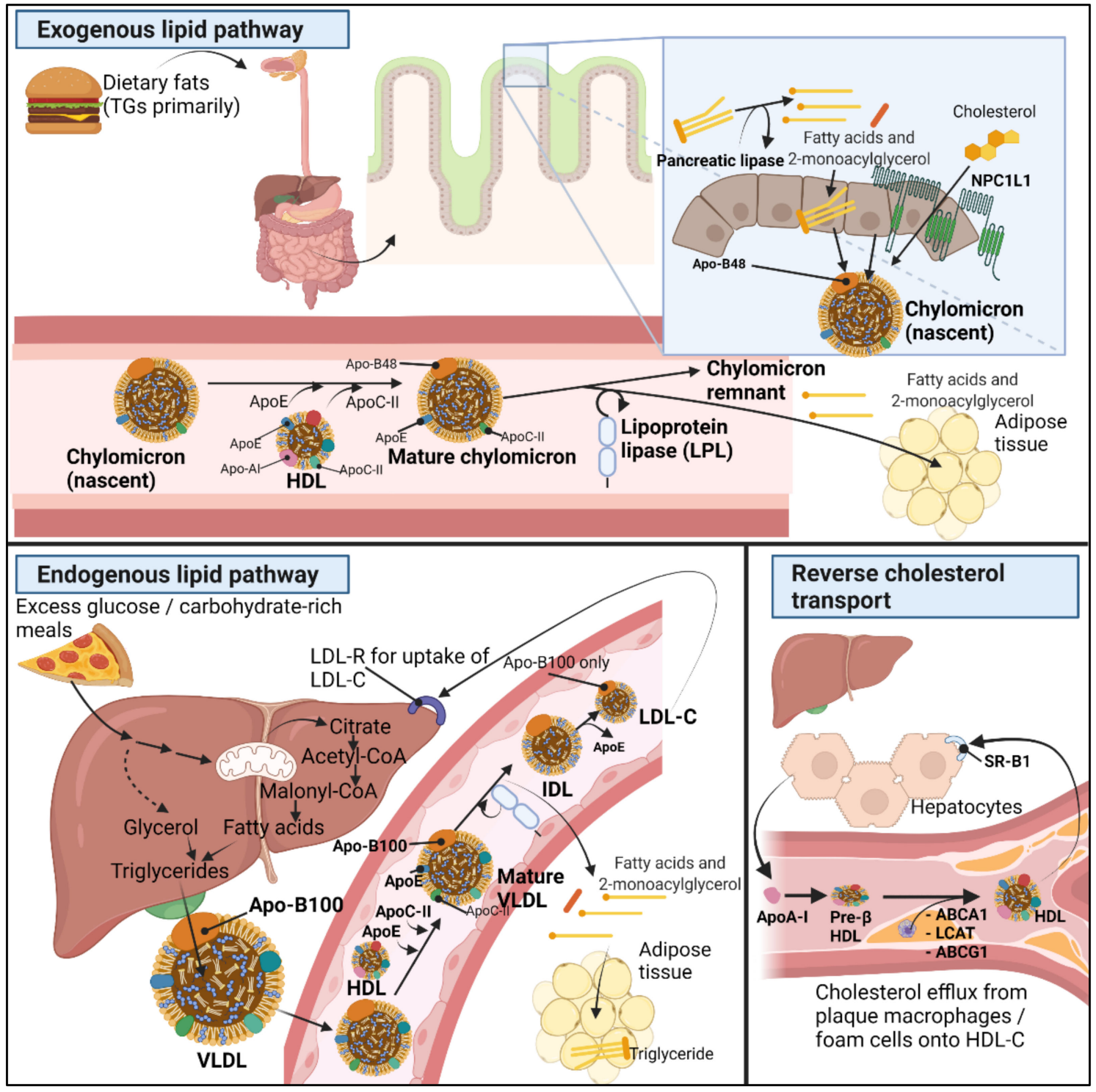

Figure 1. Normal lipid metabolism. Lipid metabolism is divided into exogenous (top) and endogenous (bottom left) lipid metabolism. Reverse cholesterol transport (bottom right) is crucial for the return of cholesterol from peripheral tissues to the liver. Further description in main text above Section 2.2. Metabolic health and dyslipidemia in patients with obesity.

In order for fatty acids to reach the peripheral tissues, lipoprotein lipase (LPL) present on the endothelial surface act on VLDL and chylomicrons to release fatty acids [23]. However, LPL cannot act on these immature chylomicron- or VLDL-molecules; therefore, with the help of high-density lipoprotein (HDL), VLDL and chylomicrons are 'matured' as HDL provides the apolipoproteins C-II (ApoC-II) and E (ApoE) [24]. Next, by connecting to 
ApoC-II, LPL is able to act on the VLDL and chylomicrons to cause the release of its fatty acid contents from its TGs [25]. However, only during high fed states the body wants to store the energy from these fatty acids. Therefore, adipocytes, only under the guidance of insulin-activated genes in adipocytes, eventually cause activation of lipoprotein lipase (LPL) on the surface of the endothelial cells of the adipocyte microcirculation [26]. In such a way, only during high-fed states, LPL takes up the fatty acids, storing TGs by enzymes which esterify fatty acids with glycerol inside adipocytes.

After transfer of TGs from VLDL into the tissues whose microcirculation express LPL and after ApoC-II is returned to HDL, the remnant molecule with often $70-80 \%$ of its triglycerides lost but most cholesteryl esters retained is called intermediate-density lipoprotein (IDL) [12]. IDL can either be further relieved of its triglycerides via hepatic lipase forming low-density lipoprotein (LDL-C), or IDL can, by hepatocyte binding with LDL-R to IDL-surface ApoE, be broken down inside hepatocytes [12]. LDL-C has lower levels of Apo-E expressed but still has surface apoB-100 expressed. Parallel to the removal of TGs from VLDL by LPL and/or formation of IDL or LDL, cholesteryl ester transferase protein (CETP) can also act on VLDL and exchange cholesteryl esters, retinyl ester, phospholipids, and triglycerides between VLDL, HDL, and LDL $[12,27,28]$.

The third arm of lipid metabolism is the reverse cholesterol transport (RCT), mediated in part by apolipoprotein AI (Apo-AI)-positive HDL particles which pick up cholesterol from the periphery including from macrophages and foam cells in the blood vessel walls. HDL-C brings cholesterol to the liver for eventual excretion in bile and feces [29,30]. HDL synthesis starts by liver and enterocyte production of Apo-AI, initially devoid of lipids (pre- $\beta$-HDL). Next, ATP-binding cassette transporter A1 (ABCA1) ensures the efflux of phosphatidylcholine and cholesterol into the pre- $\beta$-HDL to form the discoid form of HDL, a process named HDL maturation [31]. Lecithin cholesterol acyltransferase (LCAT), with the help of cofactor Apo-AI, gives esterification of cholesterol into hydrophobic cholesteryl esters, allowing sequestration of cholesterol from peripheral tissues into the lipid core of HDL. This changes the HDL shape from discoid to its mature spherical form [29,32]. HDL continues to circulate and pick up cholesterol from several peripheral tissues by action of LCAT, ATP-binding cassette transporter G1 (ABCG1), ABCA1, and eventually, HDL returns cholesterol to the liver by action of scavenger receptor class B type 1 (SR-B1) [33].

Although obesity is often complicated by dyslipidemia, there is no absolute association between obesity and dyslipidemia [34], and interestingly, certain patients of the category overweight (BMI 25-29.9 $\mathrm{kg} / \mathrm{m}^{2}$ ) have more substantial alterations in the lipid profile than patients with class III obesity (BMI above $40 \mathrm{~kg} / \mathrm{m}^{2}$ ) [35]. Some authors state this difference in a proposed disease model of a metabolic 'healthy obese' versus metabolically unhealthy normal weight individuals $[9,36,37]$, sometimes called the 'obesity paradox' or variations of this terminology $[38,39]$. In the mentioned studies emphasizing the 'healthy obese', the thought is that the risk of developing cardiometabolic disease appears to come from dyslipidemia as a separate entity or from other comorbidities such as insulin resistance and not due to obesity alone. A study by Wildman et al. of the 5440 participants in the National Health and Nutrition Examination Survey (NHANES) from 1999-2003 found that approximately $30 \%$ of the obese population and more than $50 \%$ of overweight individuals are 'metabolically healthy' [40]. The definition of 'metabolically healthy' in the mentioned study was one or less of the cardiometabolic risk factor including insulin resistance and diabetes, elevated blood pressure, systemic inflammation, and dyslipidemia [40]. Features of the metabolically healthy obese include conserved insulin sensitivity, low fat mass in visceral adipose tissue, and only minor hepatic fat contents [41]. On a cellular level, according to a review by Müller et al., in obese healthy individuals, the adipose tissue itself is of normal size and without significant hypertrophy, and there is absence of significant inflammatory infiltration by for example macrophages in the adipose tissue [41]. The question whether obesity can be termed 'healthy' is however disputed by several studies, and large systematic reviews which have shown obesity as an independent risk factor for ASCVD [42] with higher all-cause mortality of obese individuals without metabolic anomalies as com- 
pared to those of normal weight and no metabolic anomalies [43]. In addition, another study by Caleyachetty et al. showed that patients with obesity patients characterized as 'metabolically healthy' have a higher risk of cardiovascular disease (coronary heart disease, cerebrovascular disease, and heart failure) as compared to individuals with normal weight and normal metabolic parameters [44]. Furthermore, the state of metabolically healthy obese is thought to be unstable, mainly a feature of younger individuals, and possibly being only an intermediary stage before transition to a state of pathologic ('unhealthy') obesity [45].

The dyslipidemia frequently observed in patients with obesity is characterized by elevations in both fasting and postprandial triglycerides, elevated free fatty acids, reduced high-density lipoprotein cholesterol (HDL-C), high-normal to moderately increased lowdensity lipoprotein cholesterol (LDL-C), and elevations in small-dense LDL [46]. Obesity is also associated with chronic low-grade inflammation, especially by elevations in C-reactive protein $(\mathrm{CRP})$ and other proinflammatory cytokines in obese individuals as compared to lean individuals [47].

\subsection{Basic Pathogenetic Mechanisms of Dyslipidemia in the Obese Population}

Finding pathogenetic links between obesity and dyslipidemia and subsequent ASCVD is complex and incompletely understood. The mechanisms contributing to dyslipidemia in the obese include exaggerated synthesis of very low density lipoprotein (VLDL) by the liver, impairment of lipoprotein lipase (LPL) and lipolysis, LDL-receptor downregulation, reductions in HDL-C, and its related changes in neutral lipid transfer by enzymes such as CETP and phospholipid transfer protein (PTP) [34,48]. Finally, adipocyte dysfunction or 'adiposopathy' of mainly visceral adipose tissue (VAT) with adipocyte hypertrophy, adipose tissue inflammation, adipocytokine release, and excess FFA secretion are all major factors involved in the development of dyslipidemia and cardiometabolic disease [34].

Free fatty acid (FFA) turnover is the balance between FFA inflow from adipose tissue into the blood and FFA outflow into tissues whose source of energy is FFAs, such as the heart or skeletal muscle [49]. Obese individuals have elevated levels of circulating free fatty acids (FFAs) [49,50], which is thought to be due to (1) a surplus of metabolically active FFAsecreting adipocytes and (2) due to a vicious cycle of obesity-associated insulin resistance; insulin normally inhibits FFA mobilization from adipocytes, but excess of visceral adipose tissue is associated with insulin resistance [51]. Adipocytes thus release higher amounts of FFAs through excessive lipolysis, which further elevates plasma FFAs concentrations. In morbid obesity, due to excess caloric intake, adipose tissue becomes dysfunctional and with more supply of lipids than there is capacity, lipolysis increases, releasing free fatty acid systemically. These FFAs over time cause excess deposition of TGs at visceral adipose tissue but also in ectopic locations such as the liver and perivascular tissues. The deposition of FFAs in the liver leads to nonalcoholic fatty liver disease (hepatosteatosis, NAFLD), which itself contributes to increased insulin resistance and further enhancement of dyslipidemia [52]. VLDL hypersecretion occurs as the liver is meant as a glycogen-storage organ, not as a lipid- or TG-storing organ as excessive TGs can be seen as hepatotoxic. For this reason, excessive TGs are released into the circulation as VLDL, significantly contributing to raised triglyceride levels in obesity and especially in insulin-resistant patients of patients with fatty liver disease [22,52]. Apo-B-containing lipoproteins clearance is also reduced in NAFLD [53]. One of the drivers of NAFLD and ASCVD might be an altered gut microbiota composition [54].

LPL-mediated hydrolysis of triglycerides is the rate-limiting step for FFA transfer into tissues [55]. Studies have found that in obesity, there is impaired LPL activity and lipolysis, reducing the removal of postprandial FFAs and contributing to dyslipidemia through upregulated hepatic VLDL release which increases TG levels [23,56]. Finally, obesity has been associated with higher levels of CETP activity, enhancing the obesityassociated dyslipidemia with decreases in HDL-C and increases in the apo-B-containing lipoproteins $[57,58]$. 


\section{Gut Microbiota Composition in Obesity and Dyslipidemia}

Starting from the study in mice by Bäckhed et al. in 2004, which found that the introduction of gut microbiota into germ free mice increased total body fat by $57 \%$ despite diminished food intake [59], there has been substantial interest in the role of gut microbiota composition in the development of obesity. Later findings supporting the concept include the finding of obesity transmissibility through fecal matter transplantation, as was shown by Ridaura et al., where germ-free mice colonized with obese human fecal matter gave a significantly $(p \leq 0.001)$ higher fat mass and cohousing of lean and obese mice resulted in a lower change in adiposity, further suggesting transmissibility of traits such as obesity through the GM [60].

\subsection{Gut Microbiota Composition and Dyslipidemia}

The quest to identify a 'healthy set' of organisms amongst our gut microbiota has proven challenging, if not futile, at this moment and with the current knowledge. GM composition appears to change in time, vary amongst individuals despite a similar diet, and it depends on age, genetics, and environment [61-63]. Even some generally considered 'pathogenic' or 'dysbiotic' organisms are found to possibly be advantageous in other disease states [64]. The most commonly described change in GM ecology is the changes in the relative abundance of the bacterial phyla of Bacteroidetes as compared to Firmicutes in obese individuals and the increased Firmicutes-to-Bacteroidetes ratio as a predictor of obesity and cardiometabolic disease, observed in both murine models as well as in human studies [65-67]. However, further studies have shed a critical light on GM ecology as a contributing factor on itself in the development of cardiometabolic disease and obesity; in a study by Magne et al., the Firmicutes-to-Bacteroidetes ratio has been disputed as a predictor of obesity, and the study also underlined the complexity of associating this ratio with any existing health status [68]. As was written in another review by Tang et al. of related thematic, a 'knowledge gap' has developed due to research extensively attempting to portray the 'healthy' and 'unhealthy' GM ecology, whilst its produced metabolites, components, and accompanying functional changes have been overlooked to a certain extent [69]. Still, several studies have found changes in GM composition in dyslipidemia, indicating the possible role of GM in the regulation of lipid metabolism as is described in Table 1.

Table 1. Gut microbiota in relation to dyslipidemia.

\begin{tabular}{|c|c|c|c|c|}
\hline Reference & $\begin{array}{c}\text { Study } \\
\text { Description }\end{array}$ & Subjects & Methods & Main Findings \\
\hline $\begin{array}{l}\text { Fu et al., } \\
2015 \text { [70] }\end{array}$ & $\begin{array}{l}\text { Large cohort } \\
\text { study }\end{array}$ & $\begin{array}{c}893 \text { participants of } \\
\text { the LifeLines-DEEP } \\
\text { cohort }\end{array}$ & $\begin{array}{l}\text { Lipid panels of total cholesterol, HDL-C, } \\
\text { TGs, LDL-C. Sample genotyping. Fecal } \\
\text { sample gut microbiota profiling with 16s } \\
\text { rRNA gene sequencing. Operational } \\
\text { taxonomic unit (OTU) picking and OTU } \\
\text { richness. Microbial Shannon diversity } \\
\text { index calculation. Cross } \\
\text { validation analysis. }\end{array}$ & $\begin{array}{c}\text { In total, } 34 \text { bacterial taxa correlated with } \\
\text { plasma lipid levels and BMI. Specifically, } \\
\text { family Clostridiaceae/Lachnospiracease was } \\
\text { correlated with LDL. Coprococcus } \\
\text { (Firmicutes) and Collinsella had strong } \\
\text { correlation with TGs. } \\
\text { Cross validation analysis revealed that } \\
\text { GM explained } \leq 25.9 \% \text { of HDL-C } \\
\text { variance and that microbiota explained } \\
6 \% \text { of the variance in TGs. }\end{array}$ \\
\hline $\begin{array}{c}\text { Rebolledo } \\
\text { et al., } 2017 \\
\text { [71] }\end{array}$ & $\begin{array}{l}\text { Case control } \\
\text { study }\end{array}$ & $\begin{array}{l}30 \text { hypercholes- } \\
\text { terolemic subjects, } \\
27 \text { controls with } \\
\text { normal } \\
\text { cholesterol levels }\end{array}$ & $\begin{array}{l}\text { Anthropometric data. } \\
\text { Serum fasting glucose and lipid profile. } \\
\text { Stool sample analysis of GM by gel } \\
\text { electrophoresis with denaturing gradient } \\
\text { (DGGE) technique and nonmetric } \\
\text { multidimensional scaling (NMDS). } \\
\text { Shannon-Weaver, Simpson, and Richness } \\
\text { microbial community diversity indices. }\end{array}$ & $\begin{array}{l}\text { DGGE banding profiles differed between } \\
\text { case and control, confirmed by } 2 \text { separate } \\
\text { groups forming on NMDS } \\
\text { scaling analysis. } \\
\text { Significant }(p<0.05) \text { decrease of all three } \\
\text { bacterial DNA indices of } \\
\text { microbial diversity. }\end{array}$ \\
\hline
\end{tabular}


Table 1. Cont.

\begin{tabular}{|c|c|c|c|c|}
\hline Reference & $\begin{array}{c}\text { Study } \\
\text { Description }\end{array}$ & Subjects & Methods & Main Findings \\
\hline $\begin{array}{c}\text { Vojinovic } \\
\text { et al., 2019 } \\
\text { [72] }\end{array}$ & $\begin{array}{l}\text { Prospective } \\
\text { cohort study of } \\
\text { two large } \\
\text { cohorts. }\end{array}$ & $\begin{array}{l}2309 \text { individuals } \\
\text { from the Rotterdam } \\
\text { and the } \\
\text { LifeLines-DEEP } \\
\text { cohort. }\end{array}$ & $\begin{array}{l}\text { Fasting plasma metabolite profiling with } \\
{ }^{1} \mathrm{H} \text {-nuclear magnetic resonance (NMR). } \\
\text { Fecal sample gut microbiota profiling with } \\
\text { 16s rRNA gene sequencing. }\end{array}$ & $\begin{array}{l}\text { Significant }(p<0.05) \text { associations } \\
\text { between } 18 \text { families and genera of } \\
\text { bacteria with VLDL of different sizes, } \\
22 \text { with HDL, } 13 \text { with HDL and VLDL, } \\
\text { and } 15 \text { with serum triglycerides }\end{array}$ \\
\hline $\begin{array}{l}\text { Le Roy } \\
\text { et al., } 2019 \\
\text { [73] }\end{array}$ & Mouse study & $\begin{array}{l}\text { Hypercholesterolemic } \\
\text { female Apoe }{ }^{-/-} \\
\text {and } \mathrm{LDLr}^{-/-} \text {mice }\end{array}$ & $\begin{array}{c}\text { Depletion of all microbes in } \\
\text { hypercholesterolemic mice with a } \\
\text { combination of } 4 \text { antibiotics. Human feces } \\
\text { intestinal microbiota transplantation. } \\
\text { Further on mice: } \\
\text { Plasma lipid and lipoprotein profile } \\
\text { analysis. Bile acid synthesis measurement } \\
\text { with labeled }\left({ }^{14} \mathrm{C}\right) \text { cholesterol dissolved in } \\
\text { olive oil. Liver, ileum, and jejunum gene } \\
\text { expression with qPCR. Sterol quantification } \\
\text { in liver and bile. } 16 \mathrm{~S} \text { rRNA gene } \\
\text { sequencing of fecal gut microbiota. }\end{array}$ & $\begin{array}{l}\text { Depletion of microbiota in mice raises } \\
\text { cholesterol, mainly VLDL and LDL. } \\
\text { Depletion also enhances liver uptake of } \\
\text { cholesterol. Depletion increases } \\
\text { cholesterol de novo synthesis by liver. } \\
\text { Cholesterol level is transmissible in mice } \\
\text { by microbiota transplantation from } \\
\text { humans with altered cholesterol levels to } \\
\text { microbiota depleted Apoe } \\
\text { - }- \text { mice. }\end{array}$ \\
\hline $\begin{array}{l}\text { Yun et al., } \\
2020 \text { [74] }\end{array}$ & $\begin{array}{l}\text { Cross sectional } \\
\text { study }\end{array}$ & $\begin{array}{l}1141 \text { subjects from } \\
\text { the Kangbuk } \\
\text { Samsung Health } \\
\text { Study in South } \\
\text { Korea, divided into } \\
\text { dyslipidemic (G0) } \\
\text { and normal lipid } \\
\text { (G1) groups based } \\
\text { on total cholesterol, } \\
\text { LDL-C, TG, HDL-C, } \\
\text { ApoB and } \\
\text { ApoA1 levels. }\end{array}$ & $\begin{array}{l}\text { Anthropometric data. Blood sample after } \\
10 \mathrm{~h} \text { fasting of total cholesterol, } \\
\text { triglycerides, LDL-C, HDL-C, and apoA1 } \\
\text { (HDL particle component) and ApoB } \\
\text { (LDL-C and other particle } \\
\text { component) determination. } \\
\text { Gut microbiota } 16 \mathrm{~s} \text { rRNA gene sequencing } \\
\text { of fecal sample. }\end{array}$ & $\begin{array}{l}\text { The group with high TGs had lower } \\
\text { alpha diversity indices (Shannon's index } \\
\text { and Faith's phylogenetic diversity, both } \\
p<0.001 \text {, Pielou's evenness } p<0.030 \text { ). } \\
\text { Abnormally low ApoA1 group had } \\
\text { higher alpha diversity. No association } \\
\text { with alpha diversity for other } \\
\text { lipid parameters. } \\
12 \text { taxa associated with TGs: The high } \\
\text { TGs group had high amount of the genus } \\
\text { Fusobacterium and low levels of } \\
\text { Oscillospira, which produces butyrate } \\
\text { (a SCFA) } \\
10 \text { and } 6 \text { taxa were associated with } \\
\text { ApoA1 and ApoB levels, respectively. }\end{array}$ \\
\hline
\end{tabular}

\subsection{Coprostanol}

One of the earliest findings, which possibly indicates a role of GM metabolites in cholesterol metabolism, was found by a study in 1934 that identified that cholesterol transformation into coprostanol by bacterial hydrogenation was a process performed by bacteria in the colon because it did not occur after sterilization of the intestinal contents [75]. Coprostanol is the reduced form of cholesterol which cannot be absorbed and is eliminated through the feces. Furthermore, individuals can be divided into low cholesterolto-coprostanol converters and high cholesterol-to-coprostanol converters giving a bimodal distribution [76,77]. Few studies to date have explored the ability of GM to lower cholesterol levels through transformation of cholesterol into coprostanol by microbial enzymes. One recent study from 2020, by combining metagenomics and metabolomics data from several large study cohorts, identified microbial genes encoding a family of cholesterol dehydrogenase enzymes converting cholesterol into coprostanol, which they named the intestinal sterol metabolism A ( $\operatorname{IsmA}$ ) genes [78]. Furthermore, the study also found that individuals with gut microbiota producing these dehydrogenases not only had diminished levels of fecal cholesterol but also lower total cholesterol in the serum [78]. Another study found the rate of cholesterol to coprostanol conversion to be correlated with bile acids or SCFA secretion and identified 16 fecal metabolites in correlation with cholesterol conversion status [79]. The exact role of coprostanol formation in exogenous and endogenous cholesterol metabolism or the pathogenesis of dyslipidemia remains poorly understood to this day almost a century after its discovery. 


\section{Gut-Microbiota-Derived Metabolites in Dyslipidemia and Obesity}

There has been substantial evidence of a role of the gut microbiota and its metabolites in the pathogenesis of cardiometabolic disease and dyslipidemia. The aim of metabolomics is the identification of (GM-derived) metabolites in the plasma, bodily fluids, and within cells and correlates these with disease states. In the past decade, the primary method of choice to analyze metabolites in disease states has been high-frequency nuclear magnetic resonance (NMR) analysis and spectroscopy [80]. More recently, low-frequency NMR was also shown to be an easier-to-use but reliable method of identifying metabolite profiles in disease states such as T2DM [80]. Point-of-care applications of metabolomics is not possible as of now but might be so in the future, for example in assessing T2DM risk based on metabolite profiles [81]. A depiction of the role of GM metabolites in dyslipidemia and obesity can be seen in Figure 2.
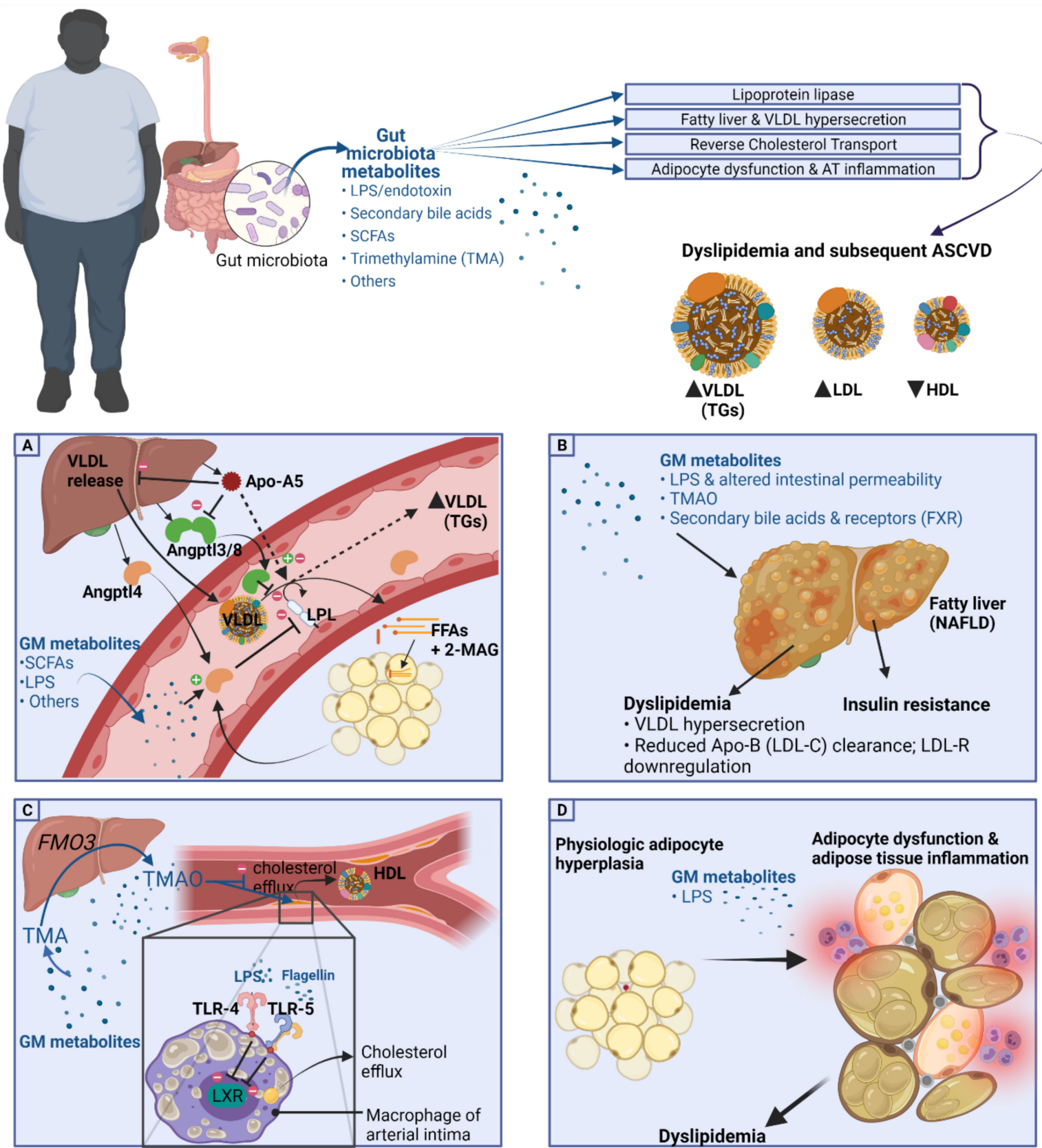

Figure 2. Gut microbiota and its metabolites in dyslipidemia. GM-produced metabolites have been associated with alterations of lipoprotein lipase function, fatty liver disease (NAFLD), inhibition of reverse cholesterol transport (RCT), and 
adipocyte dysfunction or adipose tissue inflammation. (A) Lipoprotein lipase (LPL) and GM metabolites: Studies have found that proteins which alter the function of LPL, including Angpt14, Angptl3/8, and Apo-A5, are acted upon by certain gut metabolites including SCFAs, LPS, and others, causing hypertriglyceridemia. (B) NAFLD and VLDL hypersecretion associations with gut metabolites. (C) Inhibition of reverse cholesterol transport and HDL-C by gut metabolites, primarily LPS, flagellin which upon binding to TLR-4 and TLR-5, respectively, cause inhibition of cholesterol efflux from intimal macrophages. Further metabolites include TMA and hepatically produced TMAO which possibly inhibit cholesterol efflux directly but rather contribute to ASCVD through ramping up the degree of cholesterol deposition in arterial intima macrophages, possibly through upregulation of scavenger receptor A1 and CD36 which collect oxidized LDL, and with further generation of foam cells, cause ASCVD. (D) Adipocyte dysfunction and adipose tissue inflammation in association with gut metabolites. SCFA, short-chain fatty acids; LPS, lipopolysaccharide; Angpt14 and 3, angiopoietin-like protein 4 and 3; Apo-A5, apolipoprotein A5; FFAs, free fatty acids; 2-MAG, 2-monoacylglycerol; VLDL, very low-density lipoprotein; LDL-C, low-density lipoprotein cholesterol; HDL, high-density lipoprotein; FXR, farnesoid X receptor; LXR, Liver X receptor $\alpha$ and $\beta$. TLR-4 and 5, Toll-like receptor 4 and 5 .

\subsection{Lipoprotein Lipase and GM Metabolites}

As discussed earlier, LPL-mediated TG hydrolysis is the rate-limiting step for FFA transfer into adipose and other tissues, and impairment of LPL-mediated lipolysis is one of the possible pathogenetic mechanisms leading to dyslipidemia in the obese population $[55,56]$. In mice, there have been studies implicating a role of GM or its metabolites in regulating LPL function [59]. LPL function is further regulated by adipokines and other signaling molecules such as angiopoietin-like proteins (ANGPTLs) [82] and apolipoproteins including Apo-A5 [83], and there are findings that the gut microbiota and its metabolites influence these and in such a way regulate LPL-mediated lipolysis, causing shifts in triglyceride (TG) trafficking and subsequent dyslipidemia, as is summarized in Figure 2A.

\subsubsection{Angptl4 and Angptl3}

Of the regulating factors of LPL function, the most relevant for the current discussion is angiopoietin-like protein 4 (Angpt14). Gut microbiota have been found to alter LPL function via modulation of a protein secreted by adipocytes and liver cells, termed Angptl4, or previously called 'fasting-induced adipose factor (FIAF)' [84]. Angptl4 appears to play a role in lipid metabolism via inhibition of LPL activity, thus decreasing the ability of adipocytes to take up TGs, causing hypertriglyceridemia [82,84]. Studies in mice have shown that recombinant Angpt14 injection or the induction of Angptl4 overexpression in transgenic mice increases TG levels in the plasma via inhibition of LPL activity, decreasing lipolysis of TG-rich lipoproteins such as VLDL [85-88]. The proposed function of Angptl4 is to provide fuel supply during fasting through inhibition of TG clearance and induction of lipolysis, thus increasing FFA levels in the plasma [89]. In the postprandial state, Angptl4 was shown to be inhibited by insulin, giving higher LPL activity, and thus, Angptl4 allows for the uptake of TGs from lipoproteins rich in TGs such as VLDL and chylomicrons and subsequent storage in adipocytes [89,90]. Joosen et al. showed that Angptl4 expression was lower in subcutaneous adipose tissue of study participants who were overeating, especially after the intake of the PPAR $\gamma$ ligand rosiglitazone, reiterating Angptl4's role in postprandial metabolism [91]. In humans, the Angptl4 association with TG levels remains a topic of discussion; one study by Smart-Halajako et al. did not find an association between genetic variants of Angptl4 and lipid levels or CVD [92]. A later genome wide association study by Dewey et al., however, found that the loss of function of Angptl4 (missense E40k variant) was associated with reduced triglyceride levels as well as lower coronary artery disease risk [93].

Studies connecting GM or its metabolites to LPL activity through action on Angptl4 are limited, and up till now, primarily intestinal Angptl4 regulation of lipase activity has been found to be affected by gut metabolites; Angptl4 appears to inhibit not only LPL at the adipose tissue, but also pancreatic lipase in the intestinal lumen [94]. Gut microbiota through their metabolites including SCFAs are possibly altering Angptl4 action, as was identified by a study which concluded that in human intestinal cell lines the SCFA butyrate 
induces Angptl4 function independent of PPAR $\gamma$ [84]. One study found that colonization of germ-free 8-10 week old mice by microbiota from adult conventionally raised mice ('conventionalization') gave a 57\% increase in fat tissue, a 122\% $(p<0.001)$ augmentation in LPL activity in white adipose tissue, a 99\% $(p<0.01)$ increase in heart tissue, and a drop in the LPL-inhibiting adipokine Angptl4 in the small intestines but not in adipocytes [59]. In vitro studies in cell lines have shown that SCFAs can increase Angptl4 synthesis [95], and mice colonization with the SCFA (including butyrate)-producing bacteria Clostridium tyrobutyricum was also able to increase Angptl4 in the mouse model mentioned [84]. In humans, few studies have investigated Angptl4 modulation by GM through SCFA or other metabolites. One study failed to illustrate associations between changes in the microbiota and Angptl4, did not find an influence of changes in diet on Angptl4 concentrations, and did not find a correlation between Angptl4 and plasma lipid levels [96]. However, this study investigated 18 participants, and larger studies evaluating the effect of GM or its metabolites including SCFAs on Angptl4 are therefore likely of added value.

Besides Angptl4, Angptl3 is another inhibitor of LPL, and loss-of-function mutations of Angptl3 are correlated with lower levels of TGs and cholesterol, and Angptl3 genetic deficiency is protective against ASCVD; thus, pharmacologic inhibition of Angptl3 is under current investigation as promising lipid-lowering therapy [97-99]. GM-derived LPS appears to alter Angptl3 function, as administration of LPS in mice caused a diminished Angptl3 expression [100]. Moreover, little is known about microbiota alteration of Angptl3.

\subsubsection{Apo-A5}

Another regulator of LPL activity is Apolipoprotein A5 (Apo-A5), mainly derived from the liver and to a lesser degree from intestinal enterocytes. Apo-A5 is known to decrease plasma TG levels as certain variants of the APOA5 gene have been associated with hypertriglyceridemia [101]. Although the main mechanism of Apo-A5 appears to be its ability to regulate LPL, other modes of action have been proposed such as reducing VLDL release by the liver, enhancing uptake of TG-containing particles, or by binding to the Angptl3/Angptl8 complex to cancel out its inhibition of LPL, causing an increase in LPL activity to lower plasma TG levels [83]. Cell cultures have found that SCFAs such as butyrate lead to higher Apo-A5 expression in vitro [102]. Another study found that the single-nucleotide polymorphism (SNP) of Apo-A5 minor allele, SNP rs651821, which is associated with hypertriglyceridemia, was also correlated with several microbial taxa including reductions in Actinobacteria such as Bifidobacterium. This implies influence and interaction between host genome and GM in metabolic syndrome and dyslipidemia, a relatively unexplored area [103].

\subsection{Fatty Liver and VLDL Hypersecretion Association with GM Metabolites}

Free fatty acids (FFAs) are esterified into triglycerides (TGs) for storage. The liver releases TGs into the circulation packed inside particles of VLDL, and together with enterocyte-derived chylomicrons, VLDL and chylomicrons are the main carriers of measured TG levels in the plasma. Nonalcoholic fatty liver disease (NAFLD) is strongly connected with obesity and is defined as a spectrum of liver disease including steatosis, steatohepatitis, fibrosis, and cirrhosis in order of severity occurring in the absence of alcohol use $[104,105]$. Hepatic steatosis occurs if FA inflow by hepatic FFA uptake and storage as TGs as well as de novo lipogenesis exceeds FA breakdown (oxidation) or outflow (VLDL export) [104]. NAFLD's role in dyslipidemia is thought to be through VLDL hypersecretion and altered clearance of Apo-B-containing lipoproteins including LDL-C [53]. A complicating factor of studies assessing the role of NAFLD in cardiometabolic disease is the question whether TG accumulation in the liver (steatosis) as seen in NAFLD is the cause or effect of metabolic derangements such as dyslipidemia and insulin resistance, or even both. In NAFLD, there is often co-occurrence of substantial visceral adipose tissue (VAT) expansion and ectopic fat accumulation [106]. Furthermore, considering the role of insulin in TG delivery to the liver through regulation of several pathways including LPL-mediated 
lipolysis, insulin resistance and T2D are also big contributors to hepatosteatosis [107]. As mentioned, Apo-A5 is a regulator of VLDL secretion, and Apo-A5 itself is possibly regulated through GM metabolites. Several taxa have been found to be associated with NAFLD, and the reviews addressing the role of GM and metabolites in NAFLD as well as it interventions can be found elsewhere; potential pathways appear to be through microbial LPS, altered intestinal permeability, TMAO, and secondary bile acids and their receptors such as FXR (Figure 2B) [54,108,109].

\subsection{HDL-C, Reverse Cholesterol Transport, and Cholesterol Transfer (CETP) Association with GM Metabolites}

The reverse cholesterol transport (RCT) discussed earlier ensures cholesterol efflux from tissues including vessel walls to be returned to the liver. Liver $X$ receptor (LXR) $\alpha$ and $\beta$ besides a possible role in hepatic TG accumulation appear to regulate cholesterol efflux from macrophages onto HDL-C [110]. A 2003 study indicated a role of GM in RCT as they showed that for in vitro-cultured macrophages, toll-like receptors 4 (TLR-4; activated by gram-negative bacteria-derived lipopolysaccharide) and 5 (TLR-5; activated by viral RNA) both inhibit LXR signaling and thus interrupt cholesterol efflux from macrophages (Figure 2C) [111]. However, the importance of LXR in lipid metabolism has been undermined by the finding that inducing LXR pharmacologically was not effective in altering lipids and that LXR activation by agonists did not contribute to RCT [112].

Besides GM modulation of LXR signaling, the primary GM metabolite which was found to alter reverse cholesterol transport (RCT) was the oxidized form trimethylamine, TMAO. TMA is a GM-derived metabolite produced from L-carnitine, choline, or phosphatidylcholine from our diet and is converted to the oxidized form TMAO by the liver [113]. A study in mice by Koeth et al. found that a diet high in choline or L-carnitine, giving high TMAO levels, reduced reverse cholesterol transport (RCT) activity, reducing cholesterol efflux from the periphery, and reduced the expression of bile acid transporters, causing decreased cholesterol elimination [114]. The study also showed that eliminating TMA-producing bacteria by administration of broad-spectrum antibiotics gave lower TMAO levels and also reversed the decrease in RCT as was induced by the choline- or L-carnitine-rich diet [114]. Another study found that an increase in the activity of the enzyme converting TMA into TMAO, flavin monooxygenase isotype 3 (FMO3) was associated with changes in RCT as the knockdown of FMO3 in their murine model improved RCT and cholesterol balance [115]. Interestingly, in connection with LXR discussed above, the FMO3 knockdown also increased LXR-mediated cholesterol efflux from macrophages, ameliorating dyslipidemia in mice [115].

Studies investigating the effects of GM or metabolites on CETP function are few; the idea behind CETP in RCT is that higher function of CETP (as was determined by genome wide association studies) would lower HDL-C and thus worsen dyslipidemia. One study therefore investigated a possible connection between the TMAO and CETP in 394 coronary artery disease patients and 153 control subjects but found no association between TMAO and CETP polymorphisms associated with its function [116].

The first step of HDL synthesis is the formation of Apo-AI by hepatocytes or enterocytes, and an interesting recent finding is that Apo-AI synthesis is inducible through action on Toll-like receptor 5 (TLR-5), illustrated in a high-fat diet mouse model [117]. Besides LPS, flagellin is another pathogen-associated molecular patterns (PAMPs) and binds to Toll-like receptor 5 (TLR-5), and upon binding, flagellin causes release of proinflammatory cytokines [118]. The finding of hepatic TLR- 5 and inducibility by a high-fat diet could possibly be a protective mechanism preventing metabolic derangements such as dyslipidemia after consumption of fatty meals, although this is only hypothetical for now.

\subsection{Gut Microbiota and Bile Acids in Dyslipidemia}

It is clear that bile acid formation is important in lipid metabolism, as the eventual removal of cholesterol occurs in the liver where cholesterol is converted into the primary bile acids chenodeoxycholic acid (CDCA) and cholic acid (CA) through hydroxylation 
reactions [119]. Next, primary bile acids are conjugated with glycine or taurine and excreted into the biliary tree to eventually reach the intestinal lumen where they can be acted upon by gut microbiota to form the secondary bile acids $[119,120]$. Although the majority of secreted primary bile acids are reabsorbed by terminal ileal enterocytes and (enterohepatic circulation), a proportion is not reabsorbed and reaches more distal parts where gut bacteria can dehydroxylate the primary bile acids, forming the secondary bile acids lithocholic acid (LCA), deoxycholic acid (DCA), and others [120]. Secondary bile acids are ligands for several bile acid receptors, including farnesoid $X$ receptor (FXR) and $G$ protein-coupled bile acid receptor-1 (GPBAR-1).

\subsubsection{FXR}

FXR is expressed by several tissue cells including hepatocytes, adipocytes, intestinal cells, and pancreatic islet cells, and its most potent ligand is the primary bile acid CDCA acid, but it is also acted upon by secondary bile acids such as DCA. Since the early 2000s, FXR has already been shown to have important roles in lipid metabolism [121-124], and further, FXR knockout in mice gave hypertriglyceridemia and elevations in total cholesterol [125]. Hepatic FXR activation has been shown to decrease TGs systemically through lowering hepatocyte expression of sterol regulatory element-binding protein 1c (SREBP-1c), which is a transcription factor for de novo lipogenesis in the liver [121]. FXR activation also was found to ameliorate dyslipidemia by activating FFA oxidation via PPAR $\alpha$ activation (also the gene-expression pathway for inducing HDL synthesis [122,126]), as well as by increasing apolipoprotein C-II activity [124], and decreasing hepatic VLDL production [123]. These beneficial effects of FXR on dyslipidemia sparked interest in the use of FXR agonists to treat not only triglyceride contents in the liver (NAFLD) but also dyslipidemia or hypertriglyceridemia; however, a randomized controlled trial assessing 72-week treatment with the FXR agonist obeticholic acid versus placebo in noncirrhotic NASH patients improved liver fibrosis, but total and LDL serum cholesterol was increased, while HDL-C decreased [127]. Novel trials assessing FXR modulation pharmacologically with beneficial effects on dyslipidemia are under way [128].

\subsubsection{GPBAR-1}

GPBAR-1 or Takeda G protein-coupled receptor 5 (TGR5) is another bile acid receptor and is primarily activated by LCA and DCA, both secondary and GM-derived bile acids [129]. Bile acid signaling through GPBAR-1 appears to be more involved in bile acid pool modulation, biliary epithelial permeability, energy metabolism, glucose homeostasis, and inflammation, rather than in lipid metabolism directly [130]. The only identified connection between GPBAR-1 and lipid metabolism might be the finding that GPBAR-1-null (knockout) mice are found to be relatively protected from cholesterol gallstones and that patients with cholesterol gallstones exhibit higher GPBAR-1 mRNA expression levels in their gallbladder [131,132]. Although direct regulation of lipid metabolism seems unlikely to occur through GPBAR-1, it is important to be reminded that since bile acids are the emulsifiers of ingested triglycerides and fats and GPBAR-1 appears to regulate bile acid pool and secretion, GPBAR-1 is likely to play an indirect role in lipid metabolism, possibly through modulation of lipid uptake from the gut lumen.

\subsection{Short Chain Fatty Acids and Dyslipidemia}

Short-chain fatty acids (SCFAs) are produced in the gut lumen and are water soluble, hence being readily transported across membrane transporters in enterocytes to reach the portal blood [17]. The SCFAs present with the highest concentration in the human gut are acetate, propionate, and butyrate [133]. SCFAs are produced by commensal microbiota through fermentation of indigestible non-starch polysaccharides (dietary fibers) and can function as energy source for luminal microbes themselves, can be absorbed, and used for enterocyte energy, and finally, SCFAs can be present in low amounts in the circulation and supply energy to peripheral tissues being substrates for hepatic gluconeogenesis or 
adipocyte lipogenesis [134]. Importantly, however, SCFAs when present in the circulation act on several receptors throughout the body, such as $G$ protein-coupled receptors, also termed free fatty acid receptors GPR41 (FFAR3) and GPR43 (FFAR2), olfactory receptors such as Olfr78, and others [135-137]. Higher amounts of SCFA production by the GM are increasingly seen as beneficial versus cardiometabolic disease.

As mentioned earlier, cholesterol-to-coprostanol conversion has been correlated with SCFAs [79], and SCFAs can alter LPL function through Angpt14 [84] or Apo-A5 [102]. Furthermore, stimulation of the SCFA receptor GPR43 in a mouse model and in vitro methods caused a decrease in adipocyte lipolysis, lowering free fatty acids in the plasma [138], and Hong et al. found that two SCFAs induce adipogenesis through the same receptor [139]. The inhibition of lipolysis by SCFAs was also confirmed by a study incubating adipocytes with SCFAs as they found that enhanced hormone-sensitive lipase (HSL) activity was responsible for decreased adipocyte lipolysis [140]. SCFAs supplementation has the ability to lower total cholesterol and triglycerides in several murine studies and cell models [141-143]. The cause of this beneficial effect is not completely understood, but according to Zhao et al., it might be due to SCFAs' ability to increase new bile acid synthesis as SCFAs lead to higher bile acid losses and as a balancing mechanism bile acid synthesis increases, requiring more cholesterol from the circulation hence decreasing total cholesterol in the plasma [144].

\subsection{TMAO and Lipid Metabolism}

The tertiary amine trimethylamine (TMA) is the gut-microbiota-derived metabolite produced from L-carnitine, choline, or phosphatidylcholine from our diet and is converted to the oxidized form TMAO by the liver enzyme flavin monooxygenase isotype 3 (FMO3) [113]. Original findings were that TMAO worsened dyslipidemia by, for example, reduction of reverse cholesterol transport as mentioned before [114] and that TMAO feeding increased lipid levels in mice [145]. Other studies have revealed the exact opposite, as one study in rats fed a high-fat and high-carbohydrate diet and TMAO found that TMAO supplementation decreases cholesterol absorption in the intestine through modulation of transporter proteins and decreased hepatic cholesterol indicating positive roles of TMAO [146]. TMAO is now thought to not affect plasma levels of lipids directly but rather exert its proatherogenic effects by ramping up the degree of cholesterol deposition in peripheral tissues such as the arterial intima macrophages, possibly through upregulation of scavenger receptor $\mathrm{A} 1$ and $\mathrm{CD} 36$, which collect oxidized LDL, and with further generation of foam cells, cause ASCVD (Figure 2C) [113,147]. More recent findings also explain the increased CVD risk of TMAO (in part) by its ability to augment platelet hyperreactivity and increased atherothrombosis risk, rather than its role in lipid deposition and metabolism alone [148].

\section{Adipocyte Dysfunction and Gut Metabolites}

Adipose tissue is increasingly understood as an important endocrine and metabolically active organ, storing energy efficiently and releasing modulatory adipokines such as adiponectin. Healthy adipose tissue expansion is that of hyperplasia and adaptation; maintaining vascularization, increasing insulin sensitivity partly through adiponectin release, and allowing storage of triglycerides in a 'healthy' fashion, ready for release whenever energy is required [149]. However, in case of chronic overfeeding and obesity, adipose tissue does not only undergo physiologic hyperplasia, but it also hypertrophies [150]. Hypertrophic adipocytes do not store energy efficiently, but rather they are overloaded with triglycerides and excessively large cytoplasmic lipid droplets, and upon closer investigation, these enlarged adipocytes have inadequate vascularization, deteriorated mitochondrial oxygen use, hypoxia despite increased hypoxia-inducible factor 1-alpha (HIF1 $\alpha)$, and as a result substantially increased reactive oxygen species (ROS) production, lipid peroxidation, and tissue fibrosis [149-152]. Hypertrophic adipose tissue does not allow for normal adipogenesis. With an increasing number of adipocyte progenitors over mature adipocytes, 
there is a decreased normal storage of TGs, inducing lipolysis and ectopic fat accumulation including in the liver [153,154].

Of the different types of adipose tissue frequently studied in humans, including subcutaneous and visceral adipose tissue (VAT), it is dysfunctional VAT which is believed to be the strongest driver of dyslipidemia, atherosclerosis, and cardiometabolic disease $[150,155]$. Intra-abdominal fat tissue (incl. VAT) exhibits higher lipolytic and inflammatory activity compared to subcutaneous fat tissue, which may explain that studies have consistently found a stronger association between intra-abdominal (visceral) fat and dyslipidemia and ASCVD than other fat tissue stores [155].

It appears that adipocyte hypertrophy, hypoxia, and a shift toward a proinflammatory adipose tissue drives the development of dyslipidemia and insulin resistance $[150,156]$. Adipocyte hypertrophy and dysfunction induce inflammatory changes including macrophage infiltration into fat tissue and macrophage subtype switch from M2 toward M1 macrophages, which are deemed proinflammatory [157]. Hypertrophied adipocytes secrete higher amounts of cytokines (adipokines) causing more inflammatory cell recruitment, including M1 macrophages [158]. The changes in adipocytokine secretion by mainly visceral adipocytes contribute to dyslipidemia, low-grade systemic inflammation, and ASCVD. Adipose tissue in obesity is characterized by higher levels of the proinflammatory cytokines, adipokines, and C-reactive protein (CRP), and lower levels of the anti-inflammatory and modulatory proteins such as adiponectin [159]. Figure 2D illustrates the mentioned changes and the associated gut-derived metabolites.

\subsection{GM Metabolites and Adipose Tissue Dysfunction}

In connection with impaired adipogenesis and increased preadipocytes over mature adipocytes seen in adipose tissue dysfunction, a study found that the GM-derived lipopolysaccharide (LPS) application on adipose tissue cells caused diminished adipogenesis as well as increasing premature senescence of adipocytes progenitors [160]. Other GM metabolites besides LPS have also been found to regulate adipocyte function, such as tryptophan-derived indole compounds produced by the GM, which was found to coordinate the expression of microRNA of the miR-181 family, which are regulating factors for adipocyte function [161]. The indole compounds inhibited adipocyte differentiation and TG accumulation, mainly through the miR-181 family of microRNA [161]. Finally, the endocannabinoid system (ECS) which is altered by GM, appears to regulate adipogenesis and energy balance [162,163]; however, little is known about the connection between the ECS and dyslipidemia.

Adipose function might also be related to gut microbiota through the TMA-FMO3TMAO axis. The cross-sectional study on Finnish men (METSIM, $n=10,197$ ) which performed adipose tissue biopsies on 1400 participants [164], together with other validation cohorts $[165,166]$, formed the basis for a study by Schugar et al., which found a positive correlation between FMO3 expression in human adipose tissue and obesity [167]. Moreover, by performing further analysis in mice and humans, they revealed a role for brown or beige adipose tissue; they found that adipocyte FMO3 mRNA had inverse correlation with gene expression patterns of beige or brown adipose tissue in humans, and finally, via FMO3 knockout in mice, they found higher amounts of beige adipose tissue and thus increased energy expenditure [167]. Brown and beige adipose tissue are increasingly described tissues involved in energy balance, lipid metabolism, and obesity in humans. It appears beige adipocytes are unique thermogenic cells distributed amongst white adipose tissue cells of mice and humans and have the capability to perform phenotype switch from white to brown adipose tissue in a process called 'browning' [168]. Brown and beige adipose tissue promote energy utilization by uncoupling cellular respiration from ATP synthesis and switch to thermogenesis (adaptive thermogenesis), while they increase fatty acid $\beta$-oxidation [169]. The importance of brown and beige adipose tissue in systemic metabolism was more recently highlighted by a publication that by using metabolomics proved that several metabolites are able to decrease adiposity, boosting energy expenditure, 
and improve glucose metabolism in mice [170]. Whether other gut metabolites than TMAO are actors in inducing browning of adipose tissue thus causing obesity or lipid metabolism disturbances remains to be seen.

\subsection{GM Metabolites in Adipose Tissue Inflammation}

Recent research has pointed toward a role of gut microbiota metabolites in chronic low-grade systemic inflammation [171], and it appears metabolite-induced inflammation does not only occur in the vessel wall as is seen with the metabolite TMAO [66] but also might be through inducing inflammation in our adipose tissue.

One of the earliest studies indicating that adipocytes themselves contribute to inflammation in obesity was provided by Hotamisligil et al. in 1993. As this group observed that white adipose tissue of obese mice with insulin resistance had elevated expression and synthesis of the inflammatory cytokine TNF- $\alpha$, they also found that by neutralizing the elevations in TNF- $\alpha$ by administering anti-TNF antibodies, there was substantial improvement of insulin resistance [172]. Adipose tissue inflammation is seen as an important part of the path in which obesity leads to cardiometabolic disease including dyslipidemia, T2DM, and ASCVD. Obesity independently elevates inflammatory markers such as CRP [47]. According to several studies, in obesity and physical inactivity, dysfunctional adipocytes start secreting higher amounts of the pro-inflammatory cytokines IL-1 ( $\alpha$ and $\beta$ subtypes), TNF- $\alpha$, and IL-6 [34,173,174]. Besides CRP, glycoprotein acetylation (GlycA) is another marker of systemic low-grade inflammation [175]. Mokkala et al. in a recent cross-sectional study in 335 overweight and obese pregnant women explored the value of GlycA in reflecting low-grade systemic inflammation status and gut microbiota diversity [176]. They concluded that, as compared to measured hsCRP (high-sensitivity CRP), GlycA is a better marker evaluating GM diversity and low-grade inflammation. Besides the increased pro-inflammatory markers, obesity is often associated with a decrease in adiponectin, an anti-inflammatory adipokine deemed beneficial against dyslipidemia and important in maintaining glucose and insulin homeostasis $[34,177,178]$. Another important adipokine includes the 'original' adipokine leptin, which exhibits many roles including regulating food intake [179]. In the current context, it is important to also understand leptin as a proinflammatory molecule, stimulating the release of IL- 6 and TNF- $\alpha$ in adipose tissue macrophages [180]. Interestingly, these and other proinflammatory cytokines themselves induce leptin release from adipocytes [181], creating a vicious cycle of inflammation and leptin secretion, especially when adipocytes are numerous and dysfunctional such as in obesity. More and more adipokines are being identified as well as acute phase reactants; this further underlines the role of adipose tissue as a metabolically and immunologically active endocrine organ and its possible contribution to dyslipidemia in obese but also normal-weight individuals.

Lipopolysaccharide (LPS or endotoxin) produced by gram-negative bacteria as part of its outer wall has long been known to cause systemic inflammation, as the lipid A component of LPS leads to the development of septic shock and disseminated intravascular coagulation (DIC) in case of overwhelming gram-negative bacteremia [182]. LPS is however also present in low amounts in our circulation in non-shock states as LPS has been measured in substantial amounts in our plasma but especially after meals, which is termed postprandial endotoxemia [183]. LPS works by interaction with toll-like receptor 4 (TLR-4) and CD14 abundantly present on the surface of neutrophils and macrophages, which upon activation stimulate the release of the inflammatory cytokines, TNF- $\alpha$, IL- 1 , and IL-6 [182,183]. High fat diets such as seen in obese individuals have been found to give higher amount of endotoxemia in some studies [184] but have also been disputed by others [185]. An early study in 2007 by Creely et al., which investigated the effects of LPS on obesity and T2DM, found that proinflammatory adipokines such as TNF- $\alpha$ and IL-6 were significantly $(p<0.001)$ increased in cultured human subcutaneous adipose cells treated with LPS, and they underlined that LPS works via activating an innate immune response in adipose tissue [186]. Miller at al. in a study of 192 participants observed 
positive associations between endotoxemia levels and total cholesterol, serum TGs, and insulin, while they found a negative association between endotoxemia and HDL-C [187]. LPS has already before been found in the crossroads with lipid metabolism before; in states of sepsis, HDL seems to bind and neutralize LPS and furthermore, systemic inflammatory response disrupts lipid metabolism by reducing HDL levels and increasing cholesterol and TG levels, termed the 'lipemia of sepsis' [188]. Furthermore, LPS activity, as measured by the LPS-to-HDL ratio, was found to be strongly correlated with serum TG concentration as well as with chronic inflammation in a study by Lassenius et al. analyzing data from several large cohorts [189]. Whether LPS present in low amounts contributes to dyslipidemia in other ways than a drop in HDL secondary to HDL-mediated neutralization is undetermined; however, chronic low-grade inflammation seems to be a clear component of endotoxemia.

Finally, a more novel approach is the crude identification of bacterial DNA within adipose tissue itself. In a recent study by Massier et al., ensuring strict control for contamination, bacterial DNA was identified within several adipose tissue types including the phyla of Firmicutes and Proteobacteria [190]. They also found that the quantity of bacteria as well as its distribution within adipose tissue was correlated with the degree of adipose tissue inflammation [190]. Although the exact metabolites the GM produced within the adipose tissue were not investigated in this study, it highlights the possible role of GM in adipose tissue inflammation as seen in obesity, T2DM, and dyslipidemia.

\section{Gut Microbiota Metabolites in Dietary, Weight Loss, and Pharmacologic Interventions \\ 6.1. Dietary Interventions and Gut Microbiota}

Covering the effects on dietary interventions on the GM and its metabolite production is beyond the scope of this review; however, the Mediterranean diet (MD) has received special attention in this regard. MD is a heart-healthy diet, beneficial against dyslipidemia (LDL-C reduction mainly) and decreasing CVD risk [191,192]. MD is a diet rich in fruit and vegetables, unsaturated fatty acids, wholegrain products, and overall contains high amounts of dietary fibers. Fiber-rich diets such as MD, vegetarian, or plant-based diets have been associated with substantial changes in the gut microbiota such as higher bacterial richness as compared to the Western diet which is rich in sugars, saturated fats, and contains fairly little dietary fiber [193]. In connection with dyslipidemia, one study randomizing 82 overweight and obese individuals for MD versus their regular Western diet while maintaining energy intake found that MD reduced total and LDL-cholesterol levels and that the reduction was correlated with fecal bile acid concentrations, increased bacterial gene richness, and certain shifts in GM composition [194]. The beneficial effects of dietary fiber are possibly through higher SCFAs production, as SCFAs are synthesized through fermentation of indigestible fibers by the commensal GM [134]. As the MD has substantial larger amounts of fibers, studies have found higher amounts of SCFA production with this diet, and furthermore the diet has shown to decrease Firmicutes while increasing Bacteroidetes phyla, which is relevant because Bacteroidetes is associated with increased SCFAs production [195]. Whether GM composition is merely a biomarker of the diet consumed is becoming less likely, as the diet rather appears to play an active role in altering GM composition and mediate its cardiometabolic-associated diseases.

\subsection{Weight Loss Surgery and Gut Microbiota}

As has been reviewed elsewhere [109,196,197], there is a relation between the gut microbiota or its produced metabolites and bariatric surgery such as laparoscopic Rouxen-Y gastric bypass (RYGB) or sleeve gastrectomy. Besides weight loss, bariatric surgery improves diabetes, hypertension, and NAFLD; furthermore, bariatric surgery, particularly RYGB, has been shown to greatly improve dyslipidemia in patients with obesity; and commonly observed lipid profile changes after bariatric surgery include reductions in total cholesterol and LDL-C, increments in HDL-C, and lowering of TG levels [198-200]. Whether the path by which bariatric surgery conveys beneficial changes in GM and metabo- 
lites also improves lipid metabolism is not known. One prospective study by Palmisano et al. found RYGB not only resolved hypercholesterolemia in $70.6 \%$ of patients, but also that after RYGB, there was a correlation between microbial composition and the achieved cholesterol improvement on unweighted and weighted distance matrices using BIOENV dissimilarity method [201]. Another study evaluating the role of GM in the success rate for several health parameters found that lipid metabolism was the parameter most associated with gut microbiota signatures after bariatric surgery and hypothesized that these benefits in lipid metabolism occurred due to changes in the bile acid milieu [202]. Chakaroun et al. investigated 64 individuals with and without T2DM undergoing bariatric surgery and identified a bacterial blood signature in correlation with features of the metabolic syndrome, formulating a metabolic syndrome classification index based on bacterial phylum and genus level abundances. The study also found that the weight loss and improvement of metabolic syndrome after bariatric surgery was associated with bacterial composition, quantity, and their identified taxonomic signatures [203]. The three mentioned studies investigated only 25, 24, and 64 individuals, respectively [201-203]; thus, larger studies are needed to evaluate whether benefits of bariatric surgery on dyslipidemia are, at least in part, through changes in gut microbiota or its metabolite production.

\subsection{Lipid Lowering Agents and GM}

Statins are the most widely used agents to lower LDL-C levels and work by blocking HMG-CoA reductase; however, substantial differences in treatment efficacies have been observed $[6,204,205]$. In an attempt to identify metabolite signatures, Kaddurah-Daouk et al., through targeted GC-MS metabolomics, characterized three secondary GM-derived bile acids able to anticipate the degree of the LDL-C-lowering effect of simvastatin therapy and correlated levels of secondary bile acids with simvastatin concentration [206]. The same study also revealed a correlation between coprostanol levels prior to treatment with simvastatin and the degree of LDL-C lowering in response to the statin [206]. Statins also appear to alter GM composition itself and potentially mediate some of its lipid-lowering effects through modulation of GM ecology. Vieira-Silva et al. found that the prevalence of Bacteroidetes 2 (Bact2) enterotype is lower in individuals taking statins; this Bact2 enterotype with increased Bacteroides and decreased Faecalibacterium has been correlated with systemic inflammation, loose stools, and obesity [207,208]. Likewise, another study found increases in anti-inflammatory GM ecology after atorvastatin use in humans [209]. The effects of statins on GM and GM metabolites was further emphasized by a mouse study, which revealed that statin use modified GM diversity and profile, decreased production of the SCFA butyrate, changed the bile acid pool as well as energy metabolism, and that these effects might be through the pregnane $\mathrm{X}$ receptor (PXR) [210].

Fibrates have the substantial ability to lower triglyceride levels and, to a lesser degree, can reduce LDL-C while raising HDL-C [6]. Fibrates are agonists at peroxisome proliferatoractivated receptor alpha (PPAR $\alpha$ ), a transcription factor, and fibrates thus upregulate ApoA-AI (HDL component), increasing LPL activity and fatty acid oxidation, and reduce VLDL production by the liver [211]. Although studies assessing the effect of fibrates on GM or its metabolites were not found, the receptor upon which fibrates work, PPAR $\alpha$, has been of interest in GM or GM metabolite studies. For example, high-dose SCFA acetic acid administration to mice showed increased PPAR $\alpha$ gene expression [212], and GM modulation with the nondigestible fiber $\alpha$-Cyclodextrin-modified GM but also increased PPAR $\alpha$ gene expression [213]. Personalizing the choice of lipid lowering agents based on gut microbiota composition and predicting treatment efficacy is not possible as of yet, and it is not clear whether the beneficial effects of these drugs are also acting through GM metabolite modulation.

\subsection{Supplementation and $G M$}

Probiotics are a disputable means of altering the gut microbiota composition in terms of dyslipidemia treatment. One study published this year found that Bacillus sp. DU-106 
probiotic supplementation increased bacterial richness and decreased cholesterol in hypercholesterolemic rats [214]. In humans, a randomized control trial in 128 subjects with elevated TG levels without diabetes found that supplementation with a probiotic containing L. curvatus HY7601 and L. plantarum KY1032 for 12 weeks decreased triglyceride levels while increasing LDL-C levels and increasing Apo-A5 particle size [215].

Benefits of polyunsaturated omega-3 fatty acids (hereafter 'omega-3s') supplementation on the reduction of CVD risk (including coronary artery disease or cardiovascular events) appear to be modest according to the most recent and largest-to-date systematic assessment [216]. However, the ability of omega-3s such as eicosapentaenoic acid (EPA) and docosahexaenoic acid (DHA) to reduce triglyceride levels is a more consistent finding in studies throughout [217-219]. The mechanisms by which omega-3s lower TGs are incompletely understood, possibly acting on VLDL levels by enhancement of apoB-100 turnover, causing a reduction of ApoC-III levels and subsequent induction of lipoprotein lipase, or by the action of omega-3s on peroxisome proliferator-activated receptors (PPARs) $[217,220,221]$. The effects of omega-3s on the gut microbiota or the formation of GM metabolites need further research. A randomized trial of small size (22 healthy adults) investigated omega-3-containing capsules versus a liquid form and its effects on GM composition and found higher butyrate-producing microbes following omega-3 supplementation in a reversible manner [222]. A larger study was performed in 876 female twins in the United Kingdom, which found GM alpha diversity to be correlated with omega-3s in serum; furthermore, the study found an even stronger correlation between DHA and the operational taxonomic units in the GM including the Lachnospiraceae family [223]. A recent study, which randomized patients between a 6 week supplementation of omega-3s or the prebiotic fiber of inulin, found omega-3s to cause increases in the species of Coprococcus and Bacteroides, a decrease in hepatosteatosis-related Collinsella spp., and significant increases in branched-chain fatty acids isobutyrate, isovalerate and near-significant higher levels of the SCFA butyrate; however, no significant association with alpha diversity was found [224].

\section{Conclusions}

We aimed to provide a thorough review on available literature regarding gut microbiota composition and its role on regulation of classical risk factors of cardiovascular disease including dyslipidemia, fatty liver disease, and adipose tissue dysfunction and inflammation. Moreover, we describe the emerging role of new gut-microbiota-derived metabolites including TMAO and SCFA. However, it is still not well known whether these metabolites are disease modifiers or truly causal drivers of dyslipidemia or cardiometabolic disease. Future research will have to focus on human intervention trials and large prospective cohorts aimed at altering these gut-microbiota-derived metabolites in order to reduce cardiometabolic risk.

Author Contributions: Conceptualization, M.S.Z.Z., V.E.A.G.; writing—original draft preparation, M.S.Z.Z; writing—review and editing, V.E.A.G., M.N.; visualization, M.S.Z.Z.; supervision, M.N. All authors have read and agreed to the published version of the manuscript.

Funding: Max S.Z. Zwartjes is supported by a NNF GUTMMM grant 2016 [NNF15OC0016798]. M.N. is supported by a personal ZONMW VICI grant 2020 [09150182010020].

Acknowledgments: Figures 1 and 2 were created using BioRender.com.

Conflicts of Interest: M.N. is on the Scientific Advisory Board of Caelus Health, The Netherlands, and Kaleido Biosciences, USA. None of these possible conflicts of interest bear direct relation to the content of this review. All other authors declare that they have no competing interest. 


\section{References}

1. World Health Organization. Obesity and Overweight. Available online: https://www.who.int/news-room/fact-sheets/detail/ obesity-and-overweight (accessed on 6 January 2021).

2. World Health Organization. Noncommunicable Disease Risk Factors. In World Health Statistics 2021: Monitoring Health for the SDGs, Sustainable Development Goals; World Health Statistics; World Health Organization: Geneva, Switzerland, 2021; pp. 38-39, ISBN 978-92-4-002706-0.

3. Seidell, J.C.; Halberstadt, J. The Global Burden of Obesity and the Challenges of Prevention. Ann. Nutr. Metab. 2015, 66, 7-12. [CrossRef] [PubMed]

4. Finer, N. Medical Consequences of Obesity. Medicine 2015, 43, 88-93. [CrossRef]

5. Ference, B.A.; Ginsberg, H.N.; Graham, I.; Ray, K.K.; Packard, C.J.; Bruckert, E.; Hegele, R.A.; Krauss, R.M.; Raal, F.J.; Schunkert, H.; et al. Low-Density Lipoproteins Cause Atherosclerotic Cardiovascular Disease. 1. Evidence from Genetic, Epidemiologic, and Clinical Studies. A Consensus Statement from the European Atherosclerosis Society Consensus Panel. Eur. Heart J. 2017, 38, 2459-2472. [CrossRef]

6. Mach, F.; Baigent, C.; Koskinas, K.C.; Casula, M.; Badimon, L.; Chapman, M.J.; Backer, G.G.D.; Delgado, V.; Ference, B.A.; Graham, I.M.; et al. 2019 ESC/EAS Guidelines for the Management of Dyslipidaemias: Lipid Modification to Reduce Cardiovascular Risk. Atherosclerosis 2020, 290, 140-205. [CrossRef]

7. Kopin, L.; Lowenstein, C.J. Dyslipidemia. Ann. Intern. Med. 2017, 167, ITC81. [CrossRef]

8. Townsend, N.; Wilson, L.; Bhatnagar, P.; Wickramasinghe, K.; Rayner, M.; Nichols, M. Cardiovascular Disease in Europe: Epidemiological Update 2016. Eur. Heart J. 2016, 37, 3232-3245. [CrossRef] [PubMed]

9. Smith, G.I.; Mittendorfer, B.; Klein, S. Metabolically Healthy Obesity: Facts and Fantasies. J. Clin. Investig. 2019, 129, 3978-3989. [CrossRef] [PubMed]

10. Witkowski, M.; Weeks, T.L.; Hazen, S.L. Gut Microbiota and Cardiovascular Disease. Circ. Res. 2020, 127, 553-570. [CrossRef] [PubMed]

11. Warmbrunn, M.V.; Herrema, H.; Aron-Wisnewsky, J.; Soeters, M.R.; Van Raalte, D.H.; Nieuwdorp, M. Gut Microbiota: A Promising Target against Cardiometabolic Diseases. Expert Rev. Endocrinol. Metab. 2020, 15, 13-27. [CrossRef] [PubMed]

12. Helkin, A.; Stein, J.J.; Lin, S.; Siddiqui, S.; Maier, K.G.; Gahtan, V. Dyslipidemia Part 1-Review of Lipid Metabolism and Vascular Cell Physiology. Vasc. Endovasc. Surg. 2016, 50, 107-118. [CrossRef]

13. Kindel, T.; Lee, D.M.; Tso, P. The Mechanism of the Formation and Secretion of Chylomicrons. Atheroscler. Suppl. 2010, 11, 11-16. [CrossRef] [PubMed]

14. Xiao, C.; Stahel, P.; Nahmias, A.; Lewis, G.F. Emerging Role of Lymphatics in the Regulation of Intestinal Lipid Mobilization. Front. Physiol. 2019, 10, 1604. [CrossRef] [PubMed]

15. Altmann, S.W.; Davis, H.R.; Zhu, L.-J.; Yao, X.; Hoos, L.M.; Tetzloff, G.; Iyer, S.P.N.; Maguire, M.; Golovko, A.; Zeng, M.; et al. Niemann-Pick C1 Like 1 Protein Is Critical for Intestinal Cholesterol Absorption. Science 2004, 303, 1201-1204. [CrossRef]

16. Cooper, A.D. Hepatic Uptake of Chylomicron Remnants. J. Lipid Res. 1997, 38, 2173-2192. [CrossRef]

17. Schönfeld, P.; Wojtczak, L. Short- and Medium-Chain Fatty Acids in Energy Metabolism: The Cellular Perspective. J. Lipid Res. 2016, 57, 943-954. [CrossRef]

18. Sanders, F.W.B.; Griffin, J.L. De Novo Lipogenesis in the Liver in Health and Disease: More than Just a Shunting Yard for Glucose. Biol. Rev. Camb. Philos. Soc. 2016, 91, 452-468. [CrossRef]

19. Mashima, T.; Seimiya, H.; Tsuruo, T. De Novo Fatty-Acid Synthesis and Related Pathways as Molecular Targets for Cancer Therapy. Br. J. Cancer 2009, 100, 1369-1372. [CrossRef]

20. Foster, D.W. Malonyl-CoA: The Regulator of Fatty Acid Synthesis and Oxidation. J. Clin. Investig. 2012, 122, 1958-1959. [CrossRef]

21. Brown, M.S.; Goldstein, J.L. The SREBP Pathway: Regulation of Cholesterol Metabolism by Proteolysis of a Membrane-Bound Transcription Factor. Cell 1997, 89, 331-340. [CrossRef]

22. Sparks, J.D.; Sparks, C.E.; Adeli, K. Selective Hepatic Insulin Resistance, VLDL Overproduction, and Hypertriglyceridemia. Arterioscler. Thromb. Vasc. Biol. 2012, 32, 2104-2112. [CrossRef]

23. Wang, H.; Eckel, R.H. Lipoprotein Lipase: From Gene to Obesity. Am. J. Physiol. Endocrinol. Metab. 2009, 297, E271-E288. [CrossRef] [PubMed]

24. Wolska, A.; Dunbar, R.L.; Freeman, L.A.; Ueda, M.; Amar, M.J.; Sviridov, D.O.; Remaley, A.T. Apolipoprotein C-II: New Findings Related to Genetics, Biochemistry, and Role in Triglyceride Metabolism. Atherosclerosis 2017, 267, 49-60. [CrossRef] [PubMed]

25. Kei, A.A.; Filippatos, T.D.; Tsimihodimos, V.; Elisaf, M.S. A Review of the Role of Apolipoprotein C-II in Lipoprotein Metabolism and Cardiovascular Disease. Metabolism 2012, 61, 906-921. [CrossRef]

26. Sadur, C.N.; Eckel, R.H. Insulin Stimulation of Adipose Tissue Lipoprotein Lipase. Use of the Euglycemic Clamp Technique. J. Clin. Investig. 1982, 69, 1119-1125. [CrossRef]

27. Tall, A.R. Plasma Cholesteryl Ester Transfer Protein. J. Lipid Res. 1993, 34, 1255-1274. [CrossRef]

28. Barter, P.J.; Brewer, H.B.; Chapman, M.J.; Hennekens, C.H.; Rader, D.J.; Tall, A.R. Cholesteryl Ester Transfer Protein. Arterioscler. Thromb. Vasc. Biol. 2003, 23, 160-167. [CrossRef]

29. Rosenson, R.S.; Brewer, H.B.; Davidson, W.S.; Fayad, Z.A.; Fuster, V.; Goldstein, J.; Hellerstein, M.; Jiang, X.-C.; Phillips, M.C.; Rader, D.J.; et al. Cholesterol Efflux and Atheroprotection: Advancing the Concept of Reverse Cholesterol Transport. Circulation 2012, 125, 1905-1919. [CrossRef] 
30. Tall, A.R.; Yvan-Charvet, L.; Terasaka, N.; Pagler, T.; Wang, N. HDL, ABC Transporters, and Cholesterol Efflux: Implications for the Treatment of Atherosclerosis. Cell Metab. 2008, 7, 365-375. [CrossRef]

31. März, W.; Kleber, M.E.; Scharnagl, H.; Speer, T.; Zewinger, S.; Ritsch, A.; Parhofer, K.G.; von Eckardstein, A.; Landmesser, U.; Laufs, U. HDL Cholesterol: Reappraisal of Its Clinical Relevance. Clin. Res. Cardiol. 2017, 106, 663-675. [CrossRef]

32. Gillard, B.K.; Rosales, C.; Xu, B.; Gotto, A.M.; Pownall, H.J. Rethinking Reverse Cholesterol Transport and Dysfunctional High-Density Lipoproteins. J. Clin. Lipidol. 2018, 12, 849-856. [CrossRef]

33. Zannis, V.I.; Chroni, A.; Krieger, M. Role of ApoA-I, ABCA1, LCAT, and SR-BI in the Biogenesis of HDL. J. Mol. Med. 2006, 84, 276-294. [CrossRef] [PubMed]

34. Bays, H.E.; Toth, P.P.; Kris-Etherton, P.M.; Abate, N.; Aronne, L.J.; Brown, W.V.; Gonzalez-Campoy, J.M.; Jones, S.R.; Kumar, R.; La Forge, R.; et al. Obesity, Adiposity, and Dyslipidemia: A Consensus Statement from the National Lipid Association. J. Clin. Lipidol. 2013, 7, 304-383. [CrossRef] [PubMed]

35. Bays, H.E. "Sick Fat," Metabolic Disease, and Atherosclerosis. Am. J. Med. 2009, 122, S26-S37. [CrossRef] [PubMed]

36. Stefan, N.; Häring, H.-U.; Hu, F.B.; Schulze, M.B. Metabolically Healthy Obesity: Epidemiology, Mechanisms, and Clinical Implications. Lancet Diabetes Endocrinol. 2013, 1, 152-162. [CrossRef]

37. Lorenzo, A.D. New Obesity Classification Criteria as a Tool for Bariatric Surgery Indication. WJG 2016, 22, 681. [CrossRef] [PubMed]

38. Antonopoulos, A.S.; Tousoulis, D. The Molecular Mechanisms of Obesity Paradox. Cardiovasc. Res. 2017, 113, 1074-1086. [CrossRef]

39. Mathew, H.; Farr, O.M.; Mantzoros, C.S. Metabolic Health and Weight: Understanding Metabolically Unhealthy Normal Weight or Metabolically Healthy Obese Patients. Metabolism 2016, 65, 73-80. [CrossRef]

40. Wildman, R.P.; Muntner, P.; Reynolds, K.; McGinn, A.P.; Rajpathak, S.; Wylie-Rosett, J.; Sowers, M.R. The Obese without Cardiometabolic Risk Factor Clustering and the Normal Weight with Cardiometabolic Risk Factor Clustering: Prevalence and Correlates of 2 Phenotypes among the US Population (NHANES 1999-2004). Arch. Intern. Med. 2008, 168, 1617-1624. [CrossRef]

41. Blüher, M. Mechanisms in endocrinology: Are Metabolically Healthy Obese Individuals Really Healthy? Eur. J. Endocrinol. 2014, 171, R209-R219. [CrossRef]

42. Hubert, H.B.; Feinleib, M.; McNamara, P.M.; Castelli, W.P. Obesity as an Independent Risk Factor for Cardiovascular Disease: A 26-Year Follow-up of Participants in the Framingham Heart Study. Circulation 1983, 67, 968-977. [CrossRef]

43. Kramer, C.K.; Zinman, B.; Retnakaran, R. Are Metabolically Healthy Overweight and Obesity Benign Conditions?: A Systematic Review and Meta-Analysis. Ann. Intern. Med. 2013, 159, 758. [CrossRef]

44. Caleyachetty, R.; Thomas, G.N.; Toulis, K.A.; Mohammed, N.; Gokhale, K.M.; Balachandran, K.; Nirantharakumar, K. Metabolically Healthy Obese and Incident Cardiovascular Disease Events Among 3.5 Million Men and Women. J. Am. Coll. Cardiol. 2017, 70, 1429-1437. [CrossRef] [PubMed]

45. Appleton, S.L.; Seaborn, C.J.; Visvanathan, R.; Hill, C.L.; Gill, T.K.; Taylor, A.W.; Adams, R.J. North West Adelaide Health Study Team Diabetes and Cardiovascular Disease Outcomes in the Metabolically Healthy Obese Phenotype: A Cohort Study. Diabetes Care 2013, 36, 2388-2394. [CrossRef] [PubMed]

46. Klop, B.; Elte, J.W.F.; Castro Cabezas, M. Dyslipidemia in Obesity: Mechanisms and Potential Targets. Nutrients 2013, 5, 1218-1240. [CrossRef] [PubMed]

47. Aronson, D.; Bartha, P.; Zinder, O.; Kerner, A.; Markiewicz, W.; Avizohar, O.; Brook, G.J.; Levy, Y. Obesity Is the Major Determinant of Elevated C-Reactive Protein in Subjects with the Metabolic Syndrome. Int. J. Obes. 2004, 28, 674-679. [CrossRef]

48. Rader, D.J.; Kathiresan, S. Disorders of Lipoprotein Metabolism. In Harrison's Principles of Internal Medicine, 20th ed.; McGraw-Hill Education: New York, NY, USA, 2018; Volume 2, pp. 2889-2902. ISBN 978-1-259-64404-7.

49. Björntorp, P.; Bergman, H.; Varnauskas, E. Plasma Free Fatty Acid Turnover Rate in obesity. Acta Med. Scand. 1969, 185, 351-356. [CrossRef] [PubMed]

50. Arner, P.; Rydén, M. Fatty Acids, Obesity and Insulin Resistance. Obes. Facts 2015, 8, 147-155. [CrossRef]

51. Eckel, R.H.; Grundy, S.M.; Zimmet, P.Z. The Metabolic Syndrome. Lancet 2005, 365, 1415-1428. [CrossRef]

52. Fabbrini, E.; Sullivan, S.; Klein, S. Obesity and Nonalcoholic Fatty Liver Disease: Biochemical, Metabolic, and Clinical Implications. Hepatology 2010, 51, 679-689. [CrossRef]

53. Chatrath, H.; Vuppalanchi, R.; Chalasani, N. Dyslipidemia in Patients with Nonalcoholic Fatty Liver Disease. Semin. Liver Dis. 2012, 32, 22-29. [CrossRef] [PubMed]

54. Safari, Z.; Gérard, P. The Links between the Gut Microbiome and Non-Alcoholic Fatty Liver Disease (NAFLD). Cell. Mol. Life Sci. 2019, 76, 1541-1558. [CrossRef]

55. Kersten, S. Physiological Regulation of Lipoprotein Lipase. Biochim. Et Biophys. Acta (BBA) Mol. Cell Biol. Lipids 2014, 1841, 919-933. [CrossRef]

56. Nilsson-Ehle, P. Impaired Regulation of Adipose Tissue Lipoprotein Lipase in Obesity. Int. J. Obes. 1981, 5, 695-699.

57. Arai, T.; Yamashita, S.; Hirano, K.; Sakai, N.; Kotani, K.; Fujioka, S.; Nozaki, S.; Keno, Y.; Yamane, M.; Shinohara, E. Increased Plasma Cholesteryl Ester Transfer Protein in Obese Subjects. A Possible Mechanism for the Reduction of Serum HDL Cholesterol Levels in Obesity. Arter. Thromb. 1994, 14, 1129-1136. [CrossRef] 
58. MacLean, P.S.; Vadlamudi, S.; MacDonald, K.G.; Pories, W.J.; Barakat, H.A. Suppression of Hepatic Cholesteryl Ester Transfer Protein Expression in Obese Humans with the Development of Type 2 Diabetes Mellitus. J. Clin. Endocrinol. Metab. 2005, 90, 2250-2258. [CrossRef] [PubMed]

59. Bäckhed, F.; Ding, H.; Wang, T.; Hooper, L.V.; Koh, G.Y.; Nagy, A.; Semenkovich, C.F.; Gordon, J.I. The Gut Microbiota as an Environmental Factor That Regulates Fat Storage. Proc. Natl. Acad. Sci. USA 2004, 101, 15718-15723. [CrossRef]

60. Ridaura, V.K.; Faith, J.J.; Rey, F.E.; Cheng, J.; Duncan, A.E.; Kau, A.L.; Griffin, N.W.; Lombard, V.; Henrissat, B.; Bain, J.R.; et al. Gut Microbiota from Twins Discordant for Obesity Modulate Metabolism in Mice. Science 2013, 341, 1241214. [CrossRef] [PubMed]

61. Lozupone, C.A.; Stombaugh, J.I.; Gordon, J.I.; Jansson, J.K.; Knight, R. Diversity, Stability and Resilience of the Human Gut Microbiota. Nature 2012, 489, 220-230. [CrossRef]

62. Rinninella, E.; Raoul, P.; Cintoni, M.; Franceschi, F.; Miggiano, G.; Gasbarrini, A.; Mele, M. What Is the Healthy Gut Microbiota Composition? A Changing Ecosystem across Age, Environment, Diet, and Diseases. Microorganisms 2019, 7, 14. [CrossRef] [PubMed]

63. Leeming, E.R.; Johnson, A.J.; Spector, T.D.; Le Roy, C.I. Effect of Diet on the Gut Microbiota: Rethinking Intervention Duration. Nutrients 2019, 11, 2862. [CrossRef]

64. Nicolas, S.; Blasco-Baque, V.; Fournel, A.; Gilleron, J.; Klopp, P.; Waget, A.; Ceppo, F.; Marlin, A.; Padmanabhan, R.; Iacovoni, J.S.; et al. Transfer of Dysbiotic Gut Microbiota Has Beneficial Effects on Host Liver Metabolism. Mol. Syst. Biol. 2017, 13, 921. [CrossRef]

65. Jumpertz, R.; Le, D.S.; Turnbaugh, P.J.; Trinidad, C.; Bogardus, C.; Gordon, J.I.; Krakoff, J. Energy-Balance Studies Reveal Associations between Gut Microbes, Caloric Load, and Nutrient Absorption in Humans. Am. J. Clin. Nutr. 2011, $94,58-65$. [CrossRef]

66. Yang, T.; Santisteban, M.M.; Rodriguez, V.; Li, E.; Ahmari, N.; Carvajal, J.M.; Zadeh, M.; Gong, M.; Qi, Y.; Zubcevic, J.; et al. Gut Dysbiosis Is Linked to Hypertension. Hypertension 2015, 65, 1331-1340. [CrossRef] [PubMed]

67. Ley, R.E.; Turnbaugh, P.J.; Klein, S.; Gordon, J.I. Human Gut Microbes Associated with Obesity. Nature 2006, $444,1022-1023$. [CrossRef]

68. Magne, F.; Gotteland, M.; Gauthier, L.; Zazueta, A.; Pesoa, S.; Navarrete, P.; Balamurugan, R. The Firmicutes/Bacteroidetes Ratio: A Relevant Marker of Gut Dysbiosis in Obese Patients? Nutrients 2020, 12, 1474. [CrossRef] [PubMed]

69. Tang, W.H.W.; Bäckhed, F.; Landmesser, U.; Hazen, S.L. Intestinal Microbiota in Cardiovascular Health and Disease. J. Am. Coll. Cardiol. 2019, 73, 2089-2105. [CrossRef]

70. Fu, J.; Bonder, M.J.; Cenit, M.C.; Tigchelaar, E.F.; Maatman, A.; Dekens, J.A.M.; Brandsma, E.; Marczynska, J.; Imhann, F.; Weersma, R.K.; et al. The Gut Microbiome Contributes to a Substantial Proportion of the Variation in Blood Lipids. Circ. Res. 2015, 117, 817-824. [CrossRef] [PubMed]

71. Rebolledo, C.; Cuevas, A.; Zambrano, T.; Acuña, J.J.; Jorquera, M.A.; Saavedra, K.; Martínez, C.; Lanas, F.; Serón, P.; Salazar, L.A.; et al. Bacterial Community Profile of the Gut Microbiota Differs between Hypercholesterolemic Subjects and Controls. Biomed. Res. Int. 2017, 2017, 8127814. [CrossRef] [PubMed]

72. Vojinovic, D.; Radjabzadeh, D.; Kurilshikov, A.; Amin, N.; Wijmenga, C.; Franke, L.; Ikram, M.A.; Uitterlinden, A.G.; Zhernakova, A.; Fu, J.; et al. Relationship between Gut Microbiota and Circulating Metabolites in Population-Based Cohorts. Nat. Commun. 2019, 10, 5813. [CrossRef]

73. Le Roy, T.; Lécuyer, E.; Chassaing, B.; Rhimi, M.; Lhomme, M.; Boudebbouze, S.; Ichou, F.; Haro Barceló, J.; Huby, T.; Guerin, M.; et al. The Intestinal Microbiota Regulates Host Cholesterol Homeostasis. BMC Biol. 2019, 17, 94. [CrossRef]

74. Yun, K.E.; Kim, J.; Kim, M.; Park, E.; Kim, H.-L.; Chang, Y.; Ryu, S.; Kim, H.-N. Major Lipids, Apolipoproteins, and Alterations of Gut Microbiota. JCM 2020, 9, 1589. [CrossRef]

75. Dam, H. The Formation of Coprosterol in the Intestine1: The Action of Intestinal Bacteria on Cholesterol. Biochem. J. 1934, 28, 820-825. [CrossRef]

76. Veiga, P.; Juste, C.; Lepercq, P.; Saunier, K.; Béguet, F.; Gérard, P. Correlation between Faecal Microbial Community Structure and Cholesterol-to-Coprostanol Conversion in the Human Gut. FEMS Microbiol. Lett. 2005, 242, 81-86. [CrossRef] [PubMed]

77. Kriaa, A.; Bourgin, M.; Mkaouar, H.; Jablaoui, A.; Akermi, N.; Soussou, S.; Maguin, E.; Rhimi, M. Microbial Reduction of Cholesterol to Coprostanol: An Old Concept and New Insights. Catalysts 2019, 9, 167. [CrossRef]

78. Kenny, D.J.; Plichta, D.R.; Shungin, D.; Koppel, N.; Hall, A.B.; Fu, B.; Vasan, R.S.; Shaw, S.Y.; Vlamakis, H.; Balskus, E.P.; et al. Cholesterol Metabolism by Uncultured Human Gut Bacteria Influences Host Cholesterol Level. Cell Host Microbe 2020, 28, 245-257.e6. [CrossRef] [PubMed]

79. Matysik, S.; Krautbauer, S.; Liebisch, G.; Schött, H.-F.; Kjølbaek, L.; Astrup, A.; Blachier, F.; Beaumont, M.; Nieuwdorp, M.; Hartstra, A.; et al. Short-Chain Fatty Acids and Bile Acids in Human Faeces Are Associated with the Intestinal Cholesterol Conversion Status. Br. J. Pharm. 2021, 178, 3342-3353. [CrossRef]

80. Leenders, J.; Grootveld, M.; Percival, B.; Gibson, M.; Casanova, F.; Wilson, P.B. Benchtop Low-Frequency 60 MHz NMR Analysis of Urine: A Comparative Metabolomics Investigation. Metabolites 2020, 10, 155. [CrossRef] [PubMed]

81. Percival, B.C.; Grootveld, M.; Gibson, M.; Osman, Y.; Molinari, M.; Jafari, F.; Sahota, T.; Martin, M.; Casanova, F.; Mather, M.L.; et al. Low-Field, Benchtop NMR Spectroscopy as a Potential Tool for Point-of-Care Diagnostics of Metabolic Conditions: Validation, Protocols and Computational Models. High-Throughput 2018, 8, 2. [CrossRef] [PubMed] 
82. Wu, S.A.; Kersten, S.; Qi, L. Lipoprotein Lipase and Its Regulators: An Unfolding Story. Trends Endocrinol. Metab. $2021,32,48-61$. [CrossRef]

83. Chen, Y.Q.; Pottanat, T.G.; Zhen, E.Y.; Siegel, R.W.; Ehsani, M.; Qian, Y.-W.; Konrad, R.J. ApoA5 Lowers Triglyceride Levels via Suppression of ANGPTL3/8-Mediated LPL Inhibition. J. Lipid Res. 2021, 62, 100068. [CrossRef]

84. Korecka, A.; de Wouters, T.; Cultrone, A.; Lapaque, N.; Pettersson, S.; Doré, J.; Blottière, H.M.; Arulampalam, V. ANGPTL4 Expression Induced by Butyrate and Rosiglitazone in Human Intestinal Epithelial Cells Utilizes Independent Pathways. Am. J. Physiol. Gastrointest. Liver Physiol. 2013, 304, G1025-G1037. [CrossRef] [PubMed]

85. Köster, A.; Chao, Y.B.; Mosior, M.; Ford, A.; Gonzalez-DeWhitt, P.A.; Hale, J.E.; Li, D.; Qiu, Y.; Fraser, C.C.; Yang, D.D.; et al. Transgenic Angiopoietin-Like (Angptl)4 Overexpression and Targeted Disruption of Angptl4 and Angptl3: Regulation of Triglyceride Metabolism. Endocrinology 2005, 146, 4943-4950. [CrossRef]

86. Mandard, S.; Zandbergen, F.; van Straten, E.; Wahli, W.; Kuipers, F.; Müller, M.; Kersten, S. The Fasting-Induced Adipose Factor/Angiopoietin-like Protein 4 Is Physically Associated with Lipoproteins and Governs Plasma Lipid Levels and Adiposity. J. Biol. Chem. 2006, 281, 934-944. [CrossRef] [PubMed]

87. Yoshida, K.; Shimizugawa, T.; Ono, M.; Furukawa, H. Angiopoietin-like Protein 4 Is a Potent Hyperlipidemia-Inducing Factor in Mice and Inhibitor of Lipoprotein Lipase. J. Lipid Res. 2002, 43, 1770-1772. [CrossRef] [PubMed]

88. Lichtenstein, L.; Berbée, J.F.P.; van Dijk, S.J.; van Dijk, K.W.; Bensadoun, A.; Kema, I.P.; Voshol, P.J.; Müller, M.; Rensen, P.C.N.; Kersten, S. Angptl4 Upregulates Cholesterol Synthesis in Liver via Inhibition of LPL- and HL-Dependent Hepatic Cholesterol Uptake. ATVB 2007, 27, 2420-2427. [CrossRef]

89. Kersten, S. Regulation of Lipid Metabolism via Angiopoietin-like Proteins. Biochem. Soc. Trans. 2005, 33, 4. [CrossRef]

90. Kersten, S.; Lichtenstein, L.; Steenbergen, E.; Mudde, K.; Hendriks, H.F.J.; Hesselink, M.K.; Schrauwen, P.; Müller, M. Caloric Restriction and Exercise Increase Plasma ANGPTL4 Levels in Humans via Elevated Free Fatty Acids. ATVB 2009, $29,969-974$. [CrossRef]

91. Joosen, A.M.C.P.; Bakker, A.H.F.; Kersten, S.; Westerterp, K.R. The PPAR $\gamma$ Ligand Rosiglitazone Influences Triacylglycerol Metabolism in Non-Obese Males, without Increasing the Transcriptional Activity of PPAR $\gamma$ in the Subcutaneous Adipose Tissue. Br. J. Nutr. 2008, 99, 487-493. [CrossRef] [PubMed]

92. Smart-Halajko, M.C.; Robciuc, M.R.; Cooper, J.A.; Jauhiainen, M.; Kumari, M.; Kivimaki, M.; Khaw, K.-T.; Boekholdt, S.M.; Wareham, N.J.; Gaunt, T.R.; et al. The Relationship Between Plasma Angiopoietin-like Protein 4 Levels, Angiopoietin-like Protein 4 Genotype, and Coronary Heart Disease Risk. ATVB 2010, 30, 2277-2282. [CrossRef] [PubMed]

93. Dewey, F.E.; Gusarova, V.; O’Dushlaine, C.; Gottesman, O.; Trejos, J.; Hunt, C.; Van Hout, C.V.; Habegger, L.; Buckler, D.; Lai, K.-M.V.; et al. Inactivating Variants in ANGPTL4 and Risk of Coronary Artery Disease. N. Engl. J. Med. 2016, 374, 1123-1133. [CrossRef] [PubMed]

94. Mattijssen, F.; Alex, S.; Swarts, H.J.; Groen, A.K.; van Schothorst, E.M.; Kersten, S. Angptl4 Serves as an Endogenous Inhibitor of Intestinal Lipid Digestion. Mol. Metab. 2013, 3, 135-144. [CrossRef] [PubMed]

95. Alex, S.; Lange, K.; Amolo, T.; Grinstead, J.S.; Haakonsson, A.K.; Szalowska, E.; Koppen, A.; Mudde, K.; Haenen, D.; Al-Lahham, S.; et al. Short-Chain Fatty Acids Stimulate Angiopoietin-like 4 Synthesis in Human Colon Adenocarcinoma Cells by Activating Peroxisome Proliferator-Activated Receptor $\gamma$. Mol. Cell Biol. 2013, 33, 1303-1316. [CrossRef]

96. Blædel, T.; Holm, J.B.; Sundekilde, U.K.; Schmedes, M.S.; Hess, A.L.; Lorenzen, J.K.; Kristiansen, K.; Dalsgaard, T.K.; Astrup, A.; Larsen, L.H. A Randomised, Controlled, Crossover Study of the Effect of Diet on Angiopoietin-like Protein 4 (ANGPTL4) through Modification of the Gut Microbiome. J. Nutr. Sci. 2016, 5, e45. [CrossRef] [PubMed]

97. Akoumianakis, I.; Zvintzou, E.; Kypreos, K.; Filippatos, T.D. ANGPTL3 and Apolipoprotein C-III as Novel Lipid-Lowering Targets. Curr. Atheroscler. Rep. 2021, 23, 20. [CrossRef]

98. Su, X.; Peng, D. New Insights into ANGPLT3 in Controlling Lipoprotein Metabolism and Risk of Cardiovascular Diseases. Lipids Health Dis. 2018, 17, 12. [CrossRef] [PubMed]

99. Stitziel, N.O.; Khera, A.V.; Wang, X.; Bierhals, A.J.; Vourakis, A.C.; Sperry, A.E.; Natarajan, P.; Klarin, D.; Emdin, C.A.; Zekavat, S.M.; et al. ANGPTL3 Deficiency and Protection Against Coronary Artery Disease. J. Am. Coll. Cardiol. 2017, 69, $2054-2063$. [CrossRef] [PubMed]

100. Lu, B.; Moser, A.; Shigenaga, J.K.; Grunfeld, C.; Feingold, K.R. The Acute Phase Response Stimulates the Expression of Angiopoietin like Protein 4. Biochem. Biophys. Res. Commun. 2010, 391, 1737-1741. [CrossRef]

101. Guardiola, M.; Ribalta, J. Update on APOA5 Genetics: Toward a Better Understanding of Its Physiological Impact. Curr. Atheroscler. Rep. 2017, 19, 30. [CrossRef]

102. Guardiola, M.; Alvaro, A.; Vallvé, J.C.; Rosales, R.; Solà, R.; Girona, J.; Serra, N.; Duran, P.; Esteve, E.; Masana, L.; et al. APOA5 Gene Expression in the Human Intestinal Tissue and Its Response to in Vitro Exposure to Fatty Acid and Fibrate. Nutr. Metab. Cardiovasc. Dis. 2012, 22, 756-762. [CrossRef]

103. Lim, M.Y.; You, H.J.; Yoon, H.S.; Kwon, B.; Lee, J.Y.; Lee, S.; Song, Y.-M.; Lee, K.; Sung, J.; Ko, G. The Effect of Heritability and Host Genetics on the Gut Microbiota and Metabolic Syndrome. Gut 2017, 66, 1031-1038. [CrossRef]

104. Paul, A. Nonalcoholic Fatty Liver Disease. N. Engl. J. Med. 2002, 346, 11.

105. Geisler, C.E.; Renquist, B.J. Hepatic Lipid Accumulation: Cause and Consequence of Dysregulated Glucoregulatory Hormones. J. Endocrinol. 2017, 234, R1-R21. [CrossRef] [PubMed] 
106. Perseghin, G. Lipids in the Wrong Place: Visceral Fat and Nonalcoholic Steatohepatitis. Diabetes Care 2011, 34, S367-S370. [CrossRef] [PubMed]

107. Chen, Z.; Yu, R.; Xiong, Y.; Du, F.; Zhu, S. A Vicious Circle between Insulin Resistance and Inflammation in Nonalcoholic Fatty Liver Disease. Lipids Health Dis. 2017, 16, 203. [CrossRef]

108. Aron-Wisnewsky, J.; Vigliotti, C.; Witjes, J.; Le, P.; Holleboom, A.G.; Verheij, J.; Nieuwdorp, M.; Clément, K. Gut Microbiota and Human NAFLD: Disentangling Microbial Signatures from Metabolic Disorders. Nat. Rev. Gastroenterol. Hepatol. 2020, 17, $279-297$. [CrossRef]

109. Hoozemans, J.; de Brauw, M.; Nieuwdorp, M.; Gerdes, V. Gut Microbiome and Metabolites in Patients with NAFLD and after Bariatric Surgery: A Comprehensive Review. Metabolites 2021, 11, 353. [CrossRef]

110. Baranowski, M. Biological Role of Liver X Receptors. J. Physiol. Pharm. 2008, 59 (Suppl. 7), 31-55.

111. Castrillo, A.; Joseph, S.B.; Vaidya, S.A.; Haberland, M.; Fogelman, A.M.; Cheng, G.; Tontonoz, P. Crosstalk between LXR and Toll-like Receptor Signaling Mediates Bacterial and Viral Antagonism of Cholesterol Metabolism. Mol. Cell 2003, 12, 805-816. [CrossRef]

112. Breevoort, S.R.; Angdisen, J.; Schulman, I.G. Macrophage-Independent Regulation of Reverse Cholesterol Transport by Liver X Receptors. Arter. Thromb. Vasc. Biol. 2014, 34, 1650-1660. [CrossRef] [PubMed]

113. Wang, Z.; Klipfell, E.; Bennett, B.J.; Koeth, R.; Levison, B.S.; DuGar, B.; Feldstein, A.E.; Britt, E.B.; Fu, X.; Chung, Y.-M.; et al. Gut Flora Metabolism of Phosphatidylcholine Promotes Cardiovascular Disease. Nature 2011, 472, 57-63. [CrossRef]

114. Koeth, R.A.; Wang, Z.; Levison, B.S.; Buffa, J.A.; Org, E.; Sheehy, B.T.; Britt, E.B.; Fu, X.; Wu, Y.; Li, L.; et al. Intestinal Microbiota Metabolism of L-Carnitine, a Nutrient in Red Meat, Promotes Atherosclerosis. Nat. Med. 2013, 19, 576-585. [CrossRef] [PubMed]

115. Warrier, M.; Shih, D.M.; Burrows, A.C.; Ferguson, D.; Gromovsky, A.D.; Brown, A.L.; Marshall, S.; McDaniel, A.; Schugar, R.C.; Wang, Z.; et al. The TMAO-Generating Enzyme Flavin Monooxygenase 3 Is a Central Regulator of Cholesterol Balance. Cell Rep. 2015, 10, 326-338. [CrossRef]

116. Bordoni, L.; Samulak, J.J.; Sawicka, A.K.; Pelikant-Malecka, I.; Radulska, A.; Lewicki, L.; Kalinowski, L.; Gabbianelli, R.; Olek, R.A. Trimethylamine N-Oxide and the Reverse Cholesterol Transport in Cardiovascular Disease: A Cross-Sectional Study. Sci. Rep. 2020, 10, 18675. [CrossRef]

117. Yiu, J.H.C.; Chan, K.-S.; Cheung, J.; Li, J.; Liu, Y.; Wang, Y.; Fung, W.W.L.; Cai, J.; Cheung, S.W.M.; Dorweiler, B.; et al. Gut Microbiota-Associated Activation of TLR5 Induces Apolipoprotein A1 Production in the Liver. Circ. Res. 2020, 127, 1236-1252. [CrossRef]

118. Kawai, T.; Akira, S. Toll-like Receptors and Their Crosstalk with Other Innate Receptors in Infection and Immunity. Immunity 2011, 34, 637-650. [CrossRef]

119. Šarenac, T.M.; Mikov, M. Bile Acid Synthesis: From Nature to the Chemical Modification and Synthesis and Their Applications as Drugs and Nutrients. Front. Pharm. 2018, 9, 939. [CrossRef]

120. Devlin, A.S.; Fischbach, M.A. A Biosynthetic Pathway for a Prominent Class of Microbiota-Derived Bile Acids. Nat. Chem. Biol. 2015, 11, 685-690. [CrossRef] [PubMed]

121. Watanabe, M.; Houten, S.M.; Wang, L.; Moschetta, A.; Mangelsdorf, D.J.; Heyman, R.A.; Moore, D.D.; Auwerx, J. Bile Acids Lower Triglyceride Levels via a Pathway Involving FXR, SHP, and SREBP-1c. J. Clin. Investig. 2004, 113, 1408-1418. [CrossRef]

122. Pineda Torra, I.; Claudel, T.; Duval, C.; Kosykh, V.; Fruchart, J.-C.; Staels, B. Bile Acids Induce the Expression of the Human Peroxisome Proliferator-Activated Receptor Alpha Gene via Activation of the Farnesoid X Receptor. Mol. Endocrinol. 2003, 17, $259-272$. [CrossRef] [PubMed]

123. Hirokane, H.; Nakahara, M.; Tachibana, S.; Shimizu, M.; Sato, R. Bile Acid Reduces the Secretion of Very Low Density Lipoprotein by Repressing Microsomal Triglyceride Transfer Protein Gene Expression Mediated by Hepatocyte Nuclear Factor-4. J. Biol. Chem. 2004, 279, 45685-45692. [CrossRef]

124. Kast, H.R.; Nguyen, C.M.; Sinal, C.J.; Jones, S.A.; Laffitte, B.A.; Reue, K.; Gonzalez, F.J.; Willson, T.M.; Edwards, P.A. Farnesoid X-Activated Receptor Induces Apolipoprotein C-II Transcription: A Molecular Mechanism Linking Plasma Triglyceride Levels to Bile Acids. Mol. Endocrinol. 2001, 15, 1720-1728. [CrossRef] [PubMed]

125. Sinal, C.J.; Tohkin, M.; Miyata, M.; Ward, J.M.; Lambert, G.; Gonzalez, F.J. Targeted Disruption of the Nuclear Receptor FXR/BAR Impairs Bile Acid and Lipid Homeostasis. Cell 2000, 102, 731-744. [CrossRef]

126. Colin, S.; Briand, O.; Touche, V.; Wouters, K.; Baron, M.; Pattou, F.; Hanf, R.; Tailleux, A.; Chinetti, G.; Staels, B.; et al. Activation of Intestinal Peroxisome Proliferator-Activated Receptor- $\alpha$ Increases High-Density Lipoprotein Production. Eur. Heart J. 2013, 34, 2566-2574. [CrossRef] [PubMed]

127. Neuschwander-Tetri, B.A.; Loomba, R.; Sanyal, A.J.; Lavine, J.E.; Van Natta, M.L.; Abdelmalek, M.F.; Chalasani, N.; Dasarathy, S.; Diehl, A.M.; Hameed, B.; et al. Farnesoid X Nuclear Receptor Ligand Obeticholic Acid for Non-Cirrhotic, Non-Alcoholic Steatohepatitis (FLINT): A Multicentre, Randomised, Placebo-Controlled Trial. Lancet 2015, 385, 956-965. [CrossRef]

128. Gege, C.; Hambruch, E.; Hambruch, N.; Kinzel, O.; Kremoser, C. Nonsteroidal FXR Ligands: Current Status and Clinical Applications. Handb. Exp. Pharm. 2019, 256, 167-205. [CrossRef]

129. Wahlström, A.; Sayin, S.I.; Marschall, H.-U.; Bäckhed, F. Intestinal Crosstalk between Bile Acids and Microbiota and Its Impact on Host Metabolism. Cell Metab. 2016, 24, 41-50. [CrossRef] [PubMed]

130. Portincasa, P.; Di Ciaula, A.; Garruti, G.; Vacca, M.; De Angelis, M.; Wang, D.Q.-H. Bile Acids and GPBAR-1: Dynamic Interaction Involving Genes, Environment and Gut Microbiome. Nutrients 2020, 12, 3709. [CrossRef] [PubMed] 
131. Keitel, V.; Cupisti, K.; Ullmer, C.; Knoefel, W.T.; Kubitz, R.; Häussinger, D. The Membrane-Bound Bile Acid Receptor TGR5 Is Localized in the Epithelium of Human Gallbladders. Hepatology 2009, 50, 861-870. [CrossRef]

132. Vassileva, G.; Hu, W.; Hoos, L.; Tetzloff, G.; Yang, S.; Liu, L.; Kang, L.; Davis, H.R.; Hedrick, J.A.; Lan, H.; et al. Gender-Dependent Effect of Gpbar1 Genetic Deletion on the Metabolic Profiles of Diet-Induced Obese Mice. J. Endocrinol. 2010, 205, $225-232$. [CrossRef]

133. Cummings, J.H.; Pomare, E.W.; Branch, W.J.; Naylor, C.P.; Macfarlane, G.T. Short Chain Fatty Acids in Human Large Intestine, Portal, Hepatic and Venous Blood. Gut 1987, 28, 1221-1227. [CrossRef]

134. Den Besten, G.; van Eunen, K.; Groen, A.K.; Venema, K.; Reijngoud, D.-J.; Bakker, B.M. The Role of Short-Chain Fatty Acids in the Interplay between Diet, Gut Microbiota, and Host Energy Metabolism. J. Lipid Res. 2013, 54, 2325-2340. [CrossRef] [PubMed]

135. Ang, Z.; Ding, J.L. GPR41 and GPR43 in Obesity and Inflammation-Protective or Causative? Front. Immunol. 2016, 7, 28. [CrossRef] [PubMed]

136. Layden, B.T.; Angueira, A.R.; Brodsky, M.; Durai, V.; Lowe, W.L. Short Chain Fatty Acids and Their Receptors: New Metabolic Targets. Transl. Res. 2013, 161, 131-140. [CrossRef]

137. Van der Hee, B.; Wells, J.M. Microbial Regulation of Host Physiology by Short-Chain Fatty Acids. Trends Microbiol. 2021, 29, 700-712. [CrossRef]

138. Ge, H.; Li, X.; Weiszmann, J.; Wang, P.; Baribault, H.; Chen, J.-L.; Tian, H.; Li, Y. Activation of G Protein-Coupled Receptor 43 in Adipocytes Leads to Inhibition of Lipolysis and Suppression of Plasma Free Fatty Acids. Endocrinology 2008, 149, 4519-4526. [CrossRef]

139. Hong, Y.-H.; Nishimura, Y.; Hishikawa, D.; Tsuzuki, H.; Miyahara, H.; Gotoh, C.; Choi, K.-C.; Feng, D.D.; Chen, C.; Lee, H.-G.; et al. Acetate and Propionate Short Chain Fatty Acids Stimulate Adipogenesis via GPCR43. Endocrinology 2005, 146, 5092-5099. [CrossRef] [PubMed]

140. Jocken, J.W.E.; González Hernández, M.A.; Hoebers, N.T.H.; van der Beek, C.M.; Essers, Y.P.G.; Blaak, E.E.; Canfora, E.E. Short-Chain Fatty Acids Differentially Affect Intracellular Lipolysis in a Human White Adipocyte Model. Front. Endocrinol. 2017, 8, 372. [CrossRef]

141. Hara, H.; Haga, S.; Aoyama, Y.; Kiriyama, S. Short-Chain Fatty Acids Suppress Cholesterol Synthesis in Rat Liver and Intestine. J. Nutr. 1999, 129, 942-948. [CrossRef] [PubMed]

142. Wright, R.S.; Anderson, J.W.; Bridges, S.R. Propionate Inhibits Hepatocyte Lipid Synthesis. Proc. Soc. Exp. Biol. Med. 1990, 195, 26-29. [CrossRef] [PubMed]

143. Fushimi, T.; Suruga, K.; Oshima, Y.; Fukiharu, M.; Tsukamoto, Y.; Goda, T. Dietary Acetic Acid Reduces Serum Cholesterol and Triacylglycerols in Rats Fed a Cholesterol-Rich Diet. Br. J. Nutr. 2006, 95, 916-924. [CrossRef]

144. Zhao, Y.; Liu, J.; Hao, W.; Zhu, H.; Liang, N.; He, Z.; Ma, K.Y.; Chen, Z.-Y. Structure-Specific Effects of Short-Chain Fatty Acids on Plasma Cholesterol Concentration in Male Syrian Hamsters. J. Agric. Food Chem. 2017, 65, 10984-10992. [CrossRef]

145. Ding, L.; Chang, M.; Guo, Y.; Zhang, L.; Xue, C.; Yanagita, T.; Zhang, T.; Wang, Y. Trimethylamine-N-Oxide (TMAO)-Induced Atherosclerosis Is Associated with Bile Acid Metabolism. Lipids Health Dis. 2018, 17, 286. [CrossRef]

146. Zhao, Z.-H.; Xin, F.-Z.; Zhou, D.; Xue, Y.-Q.; Liu, X.-L.; Yang, R.-X.; Pan, Q.; Fan, J.-G. Trimethylamine N-Oxide Attenuates HighFat High-Cholesterol Diet-Induced Steatohepatitis by Reducing Hepatic Cholesterol Overload in Rats. WJG 2019, 25, $2450-2462$. [CrossRef] [PubMed]

147. Zhu, Y.; Li, Q.; Jiang, H. Gut Microbiota in Atherosclerosis: Focus on Trimethylamine N-oxide. APMIS 2020, 128, 353-366. [CrossRef] [PubMed]

148. Zhu, W.; Gregory, J.C.; Org, E.; Buffa, J.A.; Gupta, N.; Wang, Z.; Li, L.; Fu, X.; Wu, Y.; Mehrabian, M.; et al. Gut Microbial Metabolite TMAO Enhances Platelet Hyperreactivity and Thrombosis Risk. Cell 2016, 165, 111-124. [CrossRef]

149. Ghaben, A.L.; Scherer, P.E. Adipogenesis and Metabolic Health. Nat. Rev. Mol. Cell Biol. 2019, 20, 242-258. [CrossRef]

150. Liu, F.; He, J.; Wang, H.; Zhu, D.; Bi, Y. Adipose Morphology: A Critical Factor in Regulation of Human Metabolic Diseases and Adipose Tissue Dysfunction. Obes. Surg. 2020, 30, 5086-5100. [CrossRef]

151. Baldini, F.; Fabbri, R.; Eberhagen, C.; Voci, A.; Portincasa, P.; Zischka, H.; Vergani, L. Adipocyte Hypertrophy Parallels Alterations of Mitochondrial Status in a Cell Model for Adipose Tissue Dysfunction in Obesity. Life Sci. 2021, 265, 118812. [CrossRef]

152. DeBari, M.K.; Abbott, R.D. Adipose Tissue Fibrosis: Mechanisms, Models, and Importance. Int. J. Mol. Sci. 2020, $21,6030$. [CrossRef]

153. Hammarstedt, A.; Gogg, S.; Hedjazifar, S.; Nerstedt, A.; Smith, U. Impaired Adipogenesis and Dysfunctional Adipose Tissue in Human Hypertrophic Obesity. Physiol. Rev. 2018, 98, 1911-1941. [CrossRef] [PubMed]

154. Jo, J.; Guo, J.; Liu, T.; Mullen, S.; Hall, K.D.; Cushman, S.W.; Periwal, V. Hypertrophy-Driven Adipocyte Death Overwhelms Recruitment under Prolonged Weight Gain. Biophys. J. 2010, 99, 3535-3544. [CrossRef]

155. Alexopoulos, N.; Katritsis, D.; Raggi, P. Visceral Adipose Tissue as a Source of Inflammation and Promoter of Atherosclerosis. Atherosclerosis 2014, 233, 104-112. [CrossRef] [PubMed]

156. Weyer, C.; Foley, J.E.; Bogardus, C.; Tataranni, P.A.; Pratley, R.E. Enlarged Subcutaneous Abdominal Adipocyte Size, but Not Obesity Itself, Predicts Type II Diabetes Independent of Insulin Resistance. Diabetologia 2000, 43, 1498-1506. [CrossRef]

157. Lumeng, C.N.; Bodzin, J.L.; Saltiel, A.R. Obesity Induces a Phenotypic Switch in Adipose Tissue Macrophage Polarization. J. Clin. Investig. 2007, 117, 175-184. [CrossRef] [PubMed] 
158. Skurk, T.; Alberti-Huber, C.; Herder, C.; Hauner, H. Relationship between Adipocyte Size and Adipokine Expression and Secretion. J. Clin. Endocrinol. Metab. 2007, 92, 1023-1033. [CrossRef] [PubMed]

159. Bays, H.E.; González-Campoy, J.M.; Bray, G.A.; Kitabchi, A.E.; Bergman, D.A.; Schorr, A.B.; Rodbard, H.W.; Henry, R.R. Pathogenic Potential of Adipose Tissue and Metabolic Consequences of Adipocyte Hypertrophy and Increased Visceral Adiposity. Expert Rev. Cardiovasc. Ther. 2008, 6, 343-368. [CrossRef]

160. Zhao, M.; Chen, X. Effect of Lipopolysaccharides on Adipogenic Potential and Premature Senescence of Adipocyte Progenitors. Am. J. Physiol. Endocrinol. Metab. 2015, 309, E334-E344. [CrossRef]

161. Virtue, A.T.; McCright, S.J.; Wright, J.M.; Jimenez, M.T.; Mowel, W.K.; Kotzin, J.J.; Joannas, L.; Basavappa, M.G.; Spencer, S.P.; Clark, M.L.; et al. The Gut Microbiota Regulates White Adipose Tissue Inflammation and Obesity via a Family of MicroRNAs. Sci. Transl. Med. 2019, 11, eaav1892. [CrossRef]

162. Muccioli, G.G.; Naslain, D.; Bäckhed, F.; Reigstad, C.S.; Lambert, D.M.; Delzenne, N.M.; Cani, P.D. The Endocannabinoid System Links Gut Microbiota to Adipogenesis. Mol. Syst. Biol. 2010, 6, 392. [CrossRef]

163. Khan, R.N.; Maner-Smith, K.; Owens, J.A.; Barbian, M.E.; Jones, R.M.; Naudin, C.R. At the Heart of Microbial Conversations: Endocannabinoids and the Microbiome in Cardiometabolic Risk. Gut Microbes 2021, 13, 1911572. [CrossRef]

164. Laakso, M.; Kuusisto, J.; Stančáková, A.; Kuulasmaa, T.; Pajukanta, P.; Lusis, A.J.; Collins, F.S.; Mohlke, K.L.; Boehnke, M. The Metabolic Syndrome in Men Study: A Resource for Studies of Metabolic and Cardiovascular Diseases. J. Lipid Res. 2017, 58, 481-493. [CrossRef]

165. Das, S.K.; Sharma, N.K.; Zhang, B. Integrative Network Analysis Reveals Different Pathophysiological Mechanisms of Insulin Resistance among Caucasians and African Americans. BMC Med. Genom. 2015, 8, 4. [CrossRef]

166. Sharma, N.K.; Sajuthi, S.P.; Chou, J.W.; Calles-Escandon, J.; Demons, J.; Rogers, S.; Ma, L.; Palmer, N.D.; McWilliams, D.R.; Beal, J.; et al. Tissue-Specific and Genetic Regulation of Insulin Sensitivity-Associated Transcripts in African Americans. J. Clin. Endocrinol. Metab. 2016, 101, 1455-1468. [CrossRef]

167. Schugar, R.C.; Shih, D.M.; Warrier, M.; Helsley, R.N.; Burrows, A.; Ferguson, D.; Brown, A.L.; Gromovsky, A.D.; Heine, M.; Chatterjee, A.; et al. The TMAO-Producing Enzyme Flavin-Containing Monooxygenase 3 Regulates Obesity and the Beiging of White Adipose Tissue. Cell Rep. 2017, 19, 2451-2461. [CrossRef] [PubMed]

168. Wu, J.; Boström, P.; Sparks, L.M.; Ye, L.; Choi, J.H.; Giang, A.-H.; Khandekar, M.; Virtanen, K.A.; Nuutila, P.; Schaart, G.; et al. Beige Adipocytes Are a Distinct Type of Thermogenic Fat Cell in Mouse and Human. Cell 2012, 150, 366-376. [CrossRef] [PubMed]

169. Ricquier, D. Uncoupling Protein 1 of Brown Adipocytes, the Only Uncoupler: A Historical Perspective. Front. Endocrin. 2011, 2, 85. [CrossRef] [PubMed]

170. Whitehead, A.; Krause, F.N.; Moran, A.; MacCannell, A.D.V.; Scragg, J.L.; McNally, B.D.; Boateng, E.; Murfitt, S.A.; Virtue, S.; Wright, J.; et al. Brown and Beige Adipose Tissue Regulate Systemic Metabolism through a Metabolite Interorgan Signaling Axis. Nat. Commun. 2021, 12, 1905. [CrossRef]

171. Le Chatelier, E.; Nielsen, T.; Qin, J.; Prifti, E.; Hildebrand, F.; Falony, G.; Almeida, M.; Arumugam, M.; Batto, J.-M.; Kennedy, S.; et al. Richness of Human Gut Microbiome Correlates with Metabolic Markers. Nature 2013, 500, 541-546. [CrossRef]

172. Hotamisligil, G.S.; Shargill, N.S.; Spiegelman, B.M. Adipose Expression of Tumor Necrosis Factor-Alpha: Direct Role in ObesityLinked Insulin Resistance. Science 1993, 259, 87-91. [CrossRef]

173. Ghanbari, M.; Momen Maragheh, S.; Aghazadeh, A.; Mehrjuyan, S.R.; Hussen, B.M.; Abdoli Shadbad, M.; Dastmalchi, N.; Safaralizadeh, R. Interleukin-1 in Obesity-Related Low-Grade Inflammation: From Molecular Mechanisms to Therapeutic Strategies. Int. Immunopharmacol. 2021, 96, 107765. [CrossRef]

174. Højbjerre, L.; Sonne, M.P.; Alibegovic, A.C.; Nielsen, N.B.; Dela, F.; Vaag, A.; Bruun, J.M.; Stallknecht, B. Impact of Physical Inactivity on Adipose Tissue Low-Grade Inflammation in First-Degree Relatives of Type 2 Diabetic Patients. Diabetes Care 2011, 34, 2265-2272. [CrossRef]

175. Otvos, J.D.; Shalaurova, I.; Wolak-Dinsmore, J.; Connelly, M.A.; Mackey, R.H.; Stein, J.H.; Tracy, R.P. GlycA: A Composite Nuclear Magnetic Resonance Biomarker of Systemic Inflammation. Clin. Chem. 2015, 61, 714-723. [CrossRef]

176. Mokkala, K.; Houttu, N.; Koivuniemi, E.; Sørensen, N.; Nielsen, H.B.; Laitinen, K. GlycA, a Novel Marker for Low Grade Inflammation, Reflects Gut Microbiome Diversity and Is More Accurate than High Sensitive CRP in Reflecting Metabolomic Profile. Metabolomics 2020, 16, 76. [CrossRef]

177. Silva, F.M.; de Almeida, J.C.; Feoli, A.M. Effect of Diet on Adiponectin Levels in Blood. Nutr. Rev. 2011, 69, 599-612. [CrossRef] [PubMed]

178. Diep Nguyen, T. Adiponectin: Role in Physiology and Pathophysiology. Int. J. Prev. Med. 2020, 11, 136. [CrossRef]

179. Obradovic, M.; Sudar-Milovanovic, E.; Soskic, S.; Essack, M.; Arya, S.; Stewart, A.J.; Gojobori, T.; Isenovic, E.R. Leptin and Obesity: Role and Clinical Implication. Front. Endocrinol. 2021, 12, 585887. [CrossRef]

180. Santos-Alvarez, J.; Goberna, R.; Sánchez-Margalet, V. Human Leptin Stimulates Proliferation and Activation of Human Circulating Monocytes. Cell. Immunol. 1999, 194, 6-11. [CrossRef] [PubMed]

181. Faggioni, R.; Fantuzzi, G.; Fuller, J.; Dinarello, C.A.; Feingold, K.R.; Grunfeld, C. IL-1 Beta Mediates Leptin Induction during Inflammation. Am. J. Physiol. 1998, 274, R204-R208. [CrossRef]

182. Raetz, C.R.H.; Whitfield, C. Lipopolysaccharide Endotoxins. Annu. Rev. Biochem. 2002, 71, 635-700. [CrossRef] [PubMed] 
183. Moludi, J.; Maleki, V.; Jafari-Vayghyan, H.; Vaghef-Mehrabany, E.; Alizadeh, M. Metabolic Endotoxemia and Cardiovascular Disease: A Systematic Review about Potential Roles of Prebiotics and Probiotics. Clin. Exp. Pharmacol. Physiol. 2020, 47, 927-939. [CrossRef] [PubMed]

184. Pendyala, S.; Walker, J.M.; Holt, P.R. A High-Fat Diet Is Associated with Endotoxemia That Originates from the Gut. Gastroenterology 2012, 142, 1100-1101.e2. [CrossRef] [PubMed]

185. Dalby, M.J.; Aviello, G.; Ross, A.W.; Walker, A.W.; Barrett, P.; Morgan, P.J. Diet Induced Obesity Is Independent of Metabolic Endotoxemia and TLR4 Signalling, but Markedly Increases Hypothalamic Expression of the Acute Phase Protein, SerpinA3N. Sci. Rep. 2018, 8, 15648. [CrossRef] [PubMed]

186. Creely, S.J.; McTernan, P.G.; Kusminski, C.M.; Fisherff, M.; Da Silva, N.F.; Khanolkar, M.; Evans, M.; Harte, A.L.; Kumar, S. Lipopolysaccharide Activates an Innate Immune System Response in Human Adipose Tissue in Obesity and Type 2 Diabetes. Am. J. Physiol. Endocrinol. Metab. 2007, 292, E740-E747. [CrossRef] [PubMed]

187. Miller, M.A.; McTernan, P.G.; Harte, A.L.; da Silva, N.F.; Strazzullo, P.; Alberti, K.G.M.M.; Kumar, S.; Cappuccio, F.P. Ethnic and Sex Differences in Circulating Endotoxin Levels: A Novel Marker of Atherosclerotic and Cardiovascular Risk in a British Multi-Ethnic Population. Atherosclerosis 2009, 203, 494-502. [CrossRef]

188. Murch, O.; Collin, M.; Hinds, C.J.; Thiemermann, C. Lipoproteins in Inflammation and Sepsis. I. Basic Science. Intensive Care Med. 2007, 33, 13-24. [CrossRef]

189. Lassenius, M.I.; Pietiläinen, K.H.; Kaartinen, K.; Pussinen, P.J.; Syrjänen, J.; Forsblom, C.; Pörsti, I.; Rissanen, A.; Kaprio, J.; Mustonen, J.; et al. Bacterial Endotoxin Activity in Human Serum Is Associated with Dyslipidemia, Insulin Resistance, Obesity, and Chronic Inflammation. Dia Care 2011, 34, 1809-1815. [CrossRef]

190. Massier, L.; Chakaroun, R.; Tabei, S.; Crane, A.; Didt, K.D.; Fallmann, J.; von Bergen, M.; Haange, S.-B.; Heyne, H.; Stumvoll, M.; et al. Adipose Tissue Derived Bacteria Are Associated with Inflammation in Obesity and Type 2 Diabetes. Gut 2020, 69, 1796-1806. [CrossRef]

191. Sofi, F.; Abbate, R.; Gensini, G.F.; Casini, A. Accruing Evidence on Benefits of Adherence to the Mediterranean Diet on Health: An Updated Systematic Review and Meta-Analysis. Am. J. Clin. Nutr. 2010, 92, 1189-1196. [CrossRef]

192. Ge, L.; Sadeghirad, B.; Ball, G.D.C.; da Costa, B.R.; Hitchcock, C.L.; Svendrovski, A.; Kiflen, R.; Quadri, K.; Kwon, H.Y.; Karamouzian, M.; et al. Comparison of Dietary Macronutrient Patterns of 14 Popular Named Dietary Programmes for Weight and Cardiovascular Risk Factor Reduction in Adults: Systematic Review and Network Meta-Analysis of Randomised Trials. BMJ 2020, 369, m696. [CrossRef]

193. Albenberg, L.G.; Wu, G.D. Diet and the Intestinal Microbiome: Associations, Functions, and Implications for Health and Disease. Gastroenterology 2014, 146, 1564-1572. [CrossRef]

194. Meslier, V.; Laiola, M.; Roager, H.M.; De Filippis, F.; Roume, H.; Quinquis, B.; Giacco, R.; Mennella, I.; Ferracane, R.; Pons, N.; et al. Mediterranean Diet Intervention in Overweight and Obese Subjects Lowers Plasma Cholesterol and Causes Changes in the Gut Microbiome and Metabolome Independently of Energy Intake. Gut 2020, 69, 1258-1268. [CrossRef] [PubMed]

195. Tsigalou, C.; Paraschaki, A.; Karvelas, A.; Kantartzi, K.; Gagali, K.; Tsairidis, D.; Bezirtzoglou, E. Gut Microbiome and Mediterranean Diet in the Context of Obesity. Current Knowledge, Perspectives and Potential Therapeutic Targets. Metab. Open 2021, 9, 100081. [CrossRef] [PubMed]

196. Davies, N.K.; O'Sullivan, J.M.; Plank, L.D.; Murphy, R. Altered Gut Microbiome after Bariatric Surgery and Its Association with Metabolic Benefits: A Systematic Review. Surg. Obes. Relat. Dis. 2019, 15, 656-665. [CrossRef]

197. Meijnikman, A.S.; Gerdes, V.E.; Nieuwdorp, M.; Herrema, H. Evaluating Causality of Gut Microbiota in Obesity and Diabetes in Humans. Endocr. Rev. 2018, 39, 133-153. [CrossRef]

198. Zlabek, J.A.; Grimm, M.S.; Larson, C.J.; Mathiason, M.A.; Lambert, P.J.; Kothari, S.N. The Effect of Laparoscopic Gastric Bypass Surgery on Dyslipidemia in Severely Obese Patients. Surg. Obes. Relat. Dis. 2005, 1, 537-542. [CrossRef]

199. Spivak, H.; Sakran, N.; Dicker, D.; Rubin, M.; Raz, I.; Shohat, T.; Blumenfeld, O. Different Effects of Bariatric Surgical Procedures on Dyslipidemia: A Registry-Based Analysis. Surg. Obes. Relat. Dis. 2017, 13, 1189-1194. [CrossRef] [PubMed]

200. Bays, H.; Kothari, S.N.; Azagury, D.E.; Morton, J.M.; Nguyen, N.T.; Jones, P.H.; Jacobson, T.A.; Cohen, D.E.; Orringer, C.; Westman, E.C.; et al. Lipids and Bariatric Procedures Part 2 of 2: Scientific Statement from the American Society for Metabolic and Bariatric Surgery (ASMBS), the National Lipid Association (NLA), and Obesity Medicine Association (OMA). Surg. Obes. Relat. Dis. 2016, 12, 468-495. [CrossRef]

201. Palmisano, S.; Campisciano, G.; Silvestri, M.; Guerra, M.; Giuricin, M.; Casagranda, B.; Comar, M.; de Manzini, N. Changes in Gut Microbiota Composition after Bariatric Surgery: A New Balance to Decode. J. Gastrointest. Surg. 2020, 24, 1736-1746. [CrossRef]

202. Gutiérrez-Repiso, C.; Moreno-Indias, I.; de Hollanda, A.; Martín-Núñez, G.M.; Vidal, J.; Tinahones, F.J. Gut Microbiota Specific Signatures Are Related to the Successful Rate of Bariatric Surgery. Am. J. Transl. Res. 2019, 11, 942-952. [PubMed]

203. Chakaroun, R.M.; Massier, L.; Heintz-Buschart, A.; Said, N.; Fallmann, J.; Crane, A.; Schütz, T.; Dietrich, A.; Blüher, M.; Stumvoll, M.; et al. Circulating Bacterial Signature Is Linked to Metabolic Disease and Shifts with Metabolic Alleviation after Bariatric Surgery. Genome Med. 2021, 13, 105. [CrossRef]

204. Collins, R.; Reith, C.; Emberson, J.; Armitage, J.; Baigent, C.; Blackwell, L.; Blumenthal, R.; Danesh, J.; Smith, G.D.; DeMets, D.; et al. Interpretation of the Evidence for the Efficacy and Safety of Statin Therapy. Lancet 2016, 388, $2532-2561$. [CrossRef]

205. Stancu, C.; Sima, A. Statins: Mechanism of Action and Effects. J. Cell Mol. Med. 2001, 5, 378-387. [CrossRef] [PubMed] 
206. Kaddurah-Daouk, R.; Baillie, R.A.; Zhu, H.; Zeng, Z.-B.; Wiest, M.M.; Nguyen, U.T.; Wojnoonski, K.; Watkins, S.M.; Trupp, M.; Krauss, R.M. Enteric Microbiome Metabolites Correlate with Response to Simvastatin Treatment. PLoS ONE 2011, 6, e25482. [CrossRef] [PubMed]

207. Vieira-Silva, S.; Falony, G.; Belda, E.; Nielsen, T.; Aron-Wisnewsky, J.; Chakaroun, R.; Forslund, S.K.; Assmann, K.; VallesColomer, M.; Nguyen, T.T.D.; et al. Statin Therapy Is Associated with Lower Prevalence of Gut Microbiota Dysbiosis. Nature 2020, 581, 310-315. [CrossRef] [PubMed]

208. Lim, G.B. Improved Gut Microbiota Profile in Individuals with Obesity Taking Statins. Nat. Rev. Cardiol. 2020, 17, 385. [CrossRef] [PubMed]

209. Khan, T.J.; Ahmed, Y.M.; Zamzami, M.A.; Siddiqui, A.M.; Khan, I.; Baothman, O.A.S.; Mehanna, M.G.; Kuerban, A.; Kaleemuddin, M.; Yasir, M. Atorvastatin Treatment Modulates the Gut Microbiota of the Hypercholesterolemic Patients. OMICS 2018, 22, 154-163. [CrossRef] [PubMed]

210. Caparrós-Martín, J.A.; Lareu, R.R.; Ramsay, J.P.; Peplies, J.; Reen, F.J.; Headlam, H.A.; Ward, N.C.; Croft, K.D.; Newsholme, P.; Hughes, J.D.; et al. Statin Therapy Causes Gut Dysbiosis in Mice through a PXR-Dependent Mechanism. Microbiome 2017, 5, 95. [CrossRef]

211. Hegele, R.A. 7-Lipoprotein and Lipid Metabolism. In Emery and Rimoin's Principles and Practice of Medical Genetics and Genomics, 7th ed; Pyeritz, R.E., Korf, B.R., Grody, W.W., Eds.; Academic Press: London, UK, 2021; pp. 235-278, ISBN 978-0-12-812535-9.

212. Kondo, T.; Kishi, M.; Fushimi, T.; Kaga, T. Acetic Acid Upregulates the Expression of Genes for Fatty Acid Oxidation Enzymes in Liver to Suppress Body Fat Accumulation. J. Agric. Food Chem. 2009, 57, 5982-5986. [CrossRef]

213. Nihei, N.; Okamoto, H.; Furune, T.; Ikuta, N.; Sasaki, K.; Rimbach, G.; Yoshikawa, Y.; Terao, K. Dietary $\alpha$-Cyclodextrin Modifies Gut Microbiota and Reduces Fat Accumulation in High-Fat-Diet-Fed Obese Mice. Biofactors 2018. [CrossRef]

214. Huang, J.; Xiao, N.; Sun, Y.; Wu, S.; Tian, W.; Lai, Y.; Li, P.; Du, B. Supplementation of Bacillus Sp. DU-106 Reduces Hypercholesterolemia and Ameliorates Gut Dysbiosis in High-Fat Diet Rats. Appl. Microbiol. Biotechnol. 2021, 105, 287-299. [CrossRef]

215. Ahn, H.Y.; Kim, M.; Chae, J.S.; Ahn, Y.-T.; Sim, J.-H.; Choi, I.-D.; Lee, S.-H.; Lee, J.H. Supplementation with Two Probiotic Strains, Lactobacillus Curvatus HY7601 and Lactobacillus Plantarum KY1032, Reduces Fasting Triglycerides and Enhances Apolipoprotein A-V Levels in Non-Diabetic Subjects with Hypertriglyceridemia. Atherosclerosis 2015, 241, 649-656. [CrossRef] [PubMed]

216. Abdelhamid, A.S.; Brown, T.J.; Brainard, J.S.; Biswas, P.; Thorpe, G.C.; Moore, H.J.; Deane, K.H.; Summerbell, C.D.; Worthington, H.V.; Song, F.; et al. Omega-3 Fatty Acids for the Primary and Secondary Prevention of Cardiovascular Disease. Cochrane Database Syst. Rev. 2020, 3, CD003177. [CrossRef] [PubMed]

217. Ferchaud-Roucher, V.; Zair, Y.; Aguesse, A.; Krempf, M.; Ouguerram, K. Omega 3 Improves Both ApoB100-Containing Lipoprotein Turnover and Their Sphingolipid Profile in Hypertriglyceridemia. J. Clin. Endocrinol. Metab. 2020, 105, dgaa459. [CrossRef]

218. Kastelein, J.J.P.; Maki, K.C.; Susekov, A.; Ezhov, M.; Nordestgaard, B.G.; Machielse, B.N.; Kling, D.; Davidson, M.H. Omega-3 Free Fatty Acids for the Treatment of Severe Hypertriglyceridemia: The EpanoVa fOr Lowering Very High TriglyceridEs (EVOLVE) Trial. J. Clin. Lipidol. 2014, 8, 94-106. [CrossRef] [PubMed]

219. Wei, M.Y.; Jacobson, T.A. Effects of Eicosapentaenoic Acid versus Docosahexaenoic Acid on Serum Lipids: A Systematic Review and Meta-Analysis. Curr. Atheroscler. Rep. 2011, 13, 474-483. [CrossRef]

220. Li, H.; Ruan, X.Z.; Powis, S.H.; Fernando, R.; Mon, W.Y.; Wheeler, D.C.; Moorhead, J.F.; Varghese, Z. EPA and DHA Reduce LPSInduced Inflammation Responses in HK-2 Cells: Evidence for a PPAR- $\gamma$-Dependent Mechanism. Kidney Int. 2005, 67, 867-874. [CrossRef]

221. Sahebkar, A.; Simental-Mendía, L.E.; Mikhailidis, D.P.; Pirro, M.; Banach, M.; Sirtori, C.R.; Reiner, Ž. Effect of Omega-3 Supplements on Plasma Apolipoprotein C-III Concentrations: A Systematic Review and Meta-Analysis of Randomized Controlled Trials. Ann. Med. 2018, 50, 565-575. [CrossRef] [PubMed]

222. Watson, H.; Mitra, S.; Croden, F.C.; Taylor, M.; Wood, H.M.; Perry, S.L.; Spencer, J.A.; Quirke, P.; Toogood, G.J.; Lawton, C.L.; et al. A Randomised Trial of the Effect of Omega-3 Polyunsaturated Fatty Acid Supplements on the Human Intestinal Microbiota. Gut 2018, 67, 1974-1983. [CrossRef]

223. Menni, C.; Zierer, J.; Pallister, T.; Jackson, M.A.; Long, T.; Mohney, R.P.; Steves, C.J.; Spector, T.D.; Valdes, A.M. Omega-3 Fatty Acids Correlate with Gut Microbiome Diversity and Production of N-Carbamylglutamate in Middle Aged and Elderly Women. Sci. Rep. 2017, 7, 11079. [CrossRef]

224. Vijay, A.; Astbury, S.; Le Roy, C.; Spector, T.D.; Valdes, A.M. The Prebiotic Effects of Omega-3 Fatty Acid Supplementation: A Six-Week Randomised Intervention Trial. Gut Microbes 2021, 13, 1-11. [CrossRef] 